\title{
Role and Mechanisms of Action of Acetylcholine in the Regulation of Rat Cholangiocyte Secretory Functions
}

\author{
D. Alvaro, ${ }^{\star}$ G. Alpini, ${ }^{\ddagger}$ A.M. Jezequel, ${ }^{\S}$ C. Bassotti, ${ }^{\|}$C. Francia, ${ }^{\star}$ F. Fraioli, ${ }^{\star}$ R. Romeo, ${ }^{\star}$ L. Marucci, ${ }^{\|}$G. Le Sage, ${ }^{\ddagger}$ S.S. Glaser, ${ }^{\ddagger}$ \\ and A. Benedettil \\ *Division of Gastroenterology, Department of Clinical Medicine, University of Rome, "La Sapienza," Viale dell'Universita' 37, 00185 \\ Rome, Italy; ${ }^{\ddagger}$ Department of Internal Medicine, Scott \& White Hospital and Texas A\&M University, Health Science Center, College of

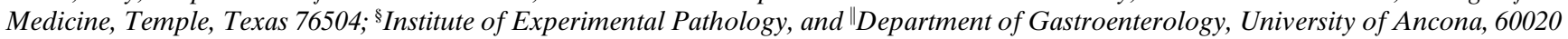 \\ Ancona, Italy
}

\begin{abstract}
We investigated, in isolated bile duct units (IBDU) and cholangiocytes isolated from normal rat liver, the occurrence of acetylcholine (ACh) receptors, and the role and mechanisms of $\mathrm{ACh}$ in the regulation of the $\mathrm{Cl}^{-} / \mathrm{HCO}_{3}{ }^{-}$exchanger activity. The $\mathrm{Cl}^{-} / \mathrm{HCO}_{3}^{-}$exchanger activity was evaluated measuring changes in intracellular $\mathrm{pH}$ induced by acute $\mathrm{Cl}^{-}$removal/readmission. $\mathrm{M} 3$ subtype $\mathrm{ACh}$ receptors were detected in IBDU and isolated cholangiocytes by immunofluorescence, immunoelectron microscopy, and reverse transcriptase PCR. M1 subtype ACh receptor mRNA was not detected by reverse transcriptase PCR and M2 subtype was negative by immunofluorescence. ACh $(10 \mu \mathrm{M})$ showed no effect on the basal activity of the $\mathrm{Cl}^{-} / \mathrm{HCO}_{3}{ }^{-}$exchanger. When IBDU were exposed to ACh plus secretin, ACh significantly $(P<0.03)$ increased the maximal rate of alkalinization after $\mathrm{Cl}^{-}$removal and the maximal rate of recovery after $\mathrm{Cl}^{-}$readmission compared with secretin alone $(50 \mathrm{nM})$, indicating that $\mathrm{ACh}$ potentiates the stimulatory effect of secretin on the $\mathrm{Cl}^{-} / \mathrm{HCO}_{3}{ }^{-}$exchanger activity. This effect of $\mathrm{ACh}$ was blocked by the M3 ACh receptor antagonist, 4-diphenyl-acetoxy- $N$-(2-chloroethyl)-piperidine (40 nM), by the intracellular $\mathrm{Ca}^{2+}$ chelator, 1,2-bis (2-Aminophenoxy)ethane- $N, N, N^{\prime}, N^{\prime}$-tetraacetic acid acetoxymethylester $(50 \mu M)$, but not by the protein kinase $\mathrm{C}$ antagonist, staurosporine $(0.1 \mu \mathrm{M})$. Intracellular cAMP levels, in isolated rat cholangiocytes, were unaffected by ACh alone, but were markedly higher after exposure to secretin plus ACh compared with secretin alone $(P<0.01)$. The $\mathrm{ACh}$-induced potentiation of the secretin effect on both intracellular cAMP levels and the $\mathrm{Cl}^{-} / \mathrm{HCO}_{3}^{-}$exchanger activity was individually abolished by two calcineurin inhibitors, FK-506 and cyclosporin A (100 nM).
\end{abstract}

Conclusions: M3 ACh receptors are markedly and diffu-

Address correspondence to Domenico Alvaro, M.D., via VALSOLDA 45/i, 00141 Rome, Italy. Phone: 39-6-4997-2023; FAX: 39-6444-0806; E-mail: alvaro@axrma.uniroma1.it

Received for publication 21 March 1997 and accepted in revised form 24 July 1997.

J. Clin. Invest.

(C) The American Society for Clinical Investigation, Inc. 0021-9738/97/09/1349/14 \$2.00

Volume 100, Number 6, September 1997, 1349-1362

http://www.jci.org sively represented in rat cholangiocytes. ACh did not influence the basal activity of the $\mathrm{Cl}^{-} / \mathrm{HCO}_{3}{ }^{-}$exchanger, but enhanced the stimulation by secretin of this anion exchanger by a $\mathrm{Ca}^{2+}$-dependent, protein kinase $\mathrm{C}$-insensitive pathway that potentiates the secretin stimulation of adenylyl cyclase. Calcineurin most likely mediates the cross-talk between the calcium and adenylyl cyclase pathways. Since secretin targets cholangiocytes during parasympathetic predominance, coordinated regulation of $\mathrm{Cl}^{-} / \mathrm{HCO}_{3}{ }^{-}$exchanger by secretin (cAMP) and $\mathrm{ACh}\left(\mathrm{Ca}^{2+}\right)$ could play a major role in the regulation of ductal bicarbonate excretion in bile just when the bicarbonate requirement in the intestine is maximal. (J. Clin. Invest. 1997. 100:1349-1362.) Key words: acetylcholine $\cdot$ secretin $\cdot \mathrm{cAMP} \cdot \mathrm{Ca}^{2+} \cdot$ calcineurin $\cdot$ adenylyl cyclase

\section{Introduction}

Cholangiocytes lining the intrahepatic biliary tree play an important role in modifying the composition of canalicular bile through secretory or reabsorptive processes (1-3). Bicarbonate excretion in bile is a major function of the biliary epithelium and is predominantly driven by an apical located $\mathrm{Cl}^{-}$/ $\mathrm{HCO}_{3}{ }^{-}$exchanger. Fluid and bicarbonate secretion from bile ducts is under hormonal regulation (1-3). Secretin (4), bombe$\sin (5)$, and vasoactive intestinal peptide (6) induce ductal choleresis by enhancing, in cholangiocytes, bicarbonate excretion through the stimulation of the $\mathrm{Cl}^{-} / \mathrm{HCO}_{3}{ }^{-}$exchanger. In contrast, somatostatin (7) and gastrin (8) inhibit ductal fluid secretion. The cholinergic system plays a fundamental role in controlling gastrointestinal physiology through the regulation of vascular, metabolic, and secretory events, as well as motility $(9,10)$. However, currently available data on the role of the cholinergic system in the regulation of bile secretion or ductal fluid secretion are scanty. In bile-fistula dogs with interrupted enterohepatic circulation, distal stimulation of the vagus nerve increases bile flow and bicarbonate biliary excretion, while vagotomy decreases basal bile flow and bicarbonate output $(11,12)$. In anaesthetized sheep (13), vagal electrical stimulation enhances bicarbonate biliary output without significant changes in bile flow. Insulin stimulation of bile flow is thought to be mediated by cholinergic mechanisms being inhibited by atropine (14). At the cellular level, the acetylcholine agonist, carbachol, induces bicarbonate rich fluid secretion in pancreatic tissue (15), salivary glands (16), and eccrine sweat glands (17), and uses $\mathrm{Ca}^{2+}$ as its intracellular messenger. As far as liver cells are concerned, while showing no effect in isolated hepatocytes, acetylcholine elicits $\mathrm{Ca}^{2+}$ increase and oscillation 
in isolated bile duct units (IBDU), ${ }^{1}$ due to both influx of extracellular $\mathrm{Ca}^{2+}$ and the mobilization of thapsigargin-sensitive $\mathrm{Ca}^{2+}$ stores (18). This indicates the presense of muscarinic receptors in the biliary system but not in hepatocytes.

The aim of this study was to investigate the occurrence of acetylcholine (ACh) receptors as well as the role and mechanisms of $\mathrm{ACh}$ in the regulation of $\mathrm{Cl}^{-} / \mathrm{HCO}_{3}{ }^{-}$exchanger activity in IBDU and in pure preparations of cholangiocytes isolated from rat liver.

\section{Methods}

\section{Materials}

ACh, secretin, carbachol, collagenase A, BSA (essential fatty acid free), EDTA, penicillin/streptomycin, heparin, Hepes, D(+)glucose, insulin, soybean trypsin inhibitor (type I-s), DMSO, deoxyribonuclease (DN-25), nigericin, $\mathrm{Na}^{+}$-gluconate, $\mathrm{K}^{+}$-gluconate, hemicalcium gluconate, 1,2-bis (2-Aminophenoxy)ethane-N,N, $\mathrm{N}^{\prime}, \mathrm{N}^{\prime}$-tetraacetic acid acetoxymethylester (BAPTA/AM), and staurosporine were purchased from Sigma Chemical Co. (St. Louis, MO). 2,7,bis(carboxyethyl)-5(6)-carboxy-fluorescein-acetomethylester (BCECF-AM) were obtained from Molecular Probes, Inc. (Eugene, OR). Liebowitz 15 (L 15), MEM, $\alpha$-MEM, L-glutamine, gentamicin, and FCS were obtained from GIBCO BRL (Gaithersburg, MD). Matrigel was from Collaborative Research Inc. (Bedford, MA), Pronase and 4-diphenylacetoxy-N-(2-chloroethyl)piperidine (4-DAMP) were from Calbiochem Corp. (La Jolla, CA). Cyclosporin A was kindly provided by Sandoz Pharma Ltd. (Basel, Switzerland) and FK-506 by Fujisawa, GmbH (Munchen, Germany). The Gene Amp ${ }^{r}$ RNA PCR core Kit was obtained from Perkin-Elmer Corp. (Norwalk, CT). The micro Fast Track ${ }^{\mathrm{TM}}$ Kit for Poly $\mathrm{A}^{+}$mRNA extraction was purchased from Invitrogen Corp. (San Diego, CA). The kit for determining intracellular cAMP levels was purchased from Amersham Corp. (Arlington Heights, IL).

\section{Isolation of bile duct units}

Male Sprague-Dawley rats (CD strain; Charles River Italia, Calco, Italy) weighing 200-270 g, were housed in temperature and light controlled rooms, maintained on a GLP diet in pellets (Nossan, Correzzana, Italy), and were given water ad libitum. Animals received humane care and the study protocol was in compliance with our institution's ethical guidelines. IBDU were prepared as described previously $(19,20)$. In brief, the animals were anesthetized intraperitoneally with pentobarbital $(50 \mathrm{mg} / \mathrm{kg})$, the portal vein was cannulated by a 16 gauge cannula and the liver perfused in situ for $10 \mathrm{~min}$ with $\mathrm{Ca}^{2+}, \mathrm{Mg}^{2+}$-free Hanks' medium/0.019\% EDTA, and then for 10-15 min with $\mathrm{Ca}^{2+}$ and $\mathrm{Mg}^{2+}$ containing Hanks' buffer supplemented with $0.05 \%$ collagenase A. The portal tissue residue was separated mechanically from parenchymal tissue and then finely minced, enzymatically digested in a solution containing collagenase $(0.066 \%)$, pronase $(0.033 \%)$, and DNase (3\%), and sequentially filtered through $100-$ and 30- $\mu \mathrm{m}$ mesh Nitex Swiss nylon monofilament screens (Tetko Co., Elmsford, NY). Fragments remaining on the filters were further digested in a solution containing pronase $(0.033 \%)$ and DNase $(3 \%)$. Fragments were then filtered again through $100-$ and $30-\mu \mathrm{m}$ mesh and those remaining on the $30-\mu \mathrm{m}$ filter were collected in $4-10 \mathrm{ml}$ $\alpha$-MEM medium supplemented with $0.1-\mu \mathrm{M}$ insulin, 3\% FCS, 2-mM

1. Abbreviations used in this paper: ACh, acetylcholine; $\beta_{\mathrm{i}}$, intrinsic buffering power; BAPTA/AM, 1,2-bis (a-Aminophenoxy)ethane$\mathrm{N}, \mathrm{N}, \mathrm{N}^{\prime}, \mathrm{N}^{\prime}$-tetraacetic acid acetoxymethylester; BCECF-AM, 2,7,bis(carboxyethyl)-5-(6)-carboxy-fluorescein-acetomethylester; 4-DAMP, 4-diphenyl-acetoxy- $N$-(2-chloroethyl)-piperidine; GAPDH, glyceraldehyde-3-phosphate dehydrogenase; IBDU, isolated bile duct units; PKC, protein kinase C; RT-PCR, reverse transcriptase PCR.
L-glutamine, gentamicin $(550 \mu \mathrm{g} / \mathrm{ml})$, and penicillin/streptomycin $(100,000 \mathrm{U}, 100 \mathrm{mg} / \mathrm{liter})$. Bile duct fragments were used for indirect immunofluorescence, immunoelectron microscopy, and for functional study as described below. For indirect immunofluorescence, part of the material was embedded in Tissue Tek, snap-frozen in isopentane precooled in liquid nitrogen and stored at $-70^{\circ} \mathrm{C}$. $4-\mu \mathrm{m}$-thick cryostat sections were cut, placed on gelatin-coated slides, and fixed in absolute acetone for $10 \mathrm{~min}$. For immunoelectron microscopy, small fragments of IBDU were fixed in periodate-lysine-paraformaldehyde for $1 \mathrm{~h}$ at $4^{\circ} \mathrm{C}$, rinsed in PBS, and exposed to the antibody as shown below. The functional study fragments were plated on small coverslips, $(4 \times 2 \mathrm{~mm})$, layered in $12-\mathrm{mm}$ diameter tissue culture plastic wells (Corning Glass Works, Corning, NY), covered with a thin layer of Matrigel and incubated at $37^{\circ} \mathrm{C}$ in a $95 \% \mathrm{O}_{2} / 5 \% \mathrm{CO}_{2}$-equilibrated incubator. The medium was changed after $24 \mathrm{~h}$ and the experiments performed between $24-48 \mathrm{~h}$ after plating. Viability (trypan blue exclusion) was evaluated in plated IBDU at the beginning and end of the functional study and in the presence of both agonists and antagonists.

\section{Light microscopy}

Indirect immunofluorescence. The sections were rinsed in PBS and incubated for $1 \mathrm{~h}$ at room temperature in normal sera to suppress nonspecific antibody binding. Thereafter, the sections were incubated overnight at $4^{\circ} \mathrm{C}$ with mouse anti-mAChR mAb M35 monoclonal antibody $(50 \mu \mathrm{g} / \mathrm{ml}$; Chemunex, Maisons-Alfort, France) $(n=25)$ in PBS. In paired experiments $(n=20)$, the sections were preincubated with $40 \mathrm{nM}$ of 4-DAMP for $30 \mathrm{~min}$ at room temperature and then incubated with M35 mAb as described previously. The M35 antibody was raised in mice against muscarinic receptor protein purified from bovine forebrain homogenates and was shown to recognize the M2 and M3 subtypes (21-23). PBS was only used in negative controls. Binding of mAb M35 was visualized by exposure to goat anti-mouse IgG conjugated with FITC (Sigma Chemical Co.; F-5897). In different experiments $(n=15)$, the sections were incubated overnight at $4^{\circ} \mathrm{C}$ with $\mathrm{M} 2$ muscarinic ACh receptor $\mathrm{mAb}(2 \mu \mathrm{g} / \mathrm{ml}$; Chemicon International Inc., Temecula, CA) in PBS. The M2 muscarinic ACh receptor $\mathrm{mAb}$ is specific for the $\mathrm{M} 2$ receptor and shows no cross-reactivity with the other subtypes (M1, M2, or M4). PBS only was used in negative controls. The fluorescent signal was analyzed by a quantitative image analysis system (Olympus Cue-3 versus Image analyzer) connected to an Olympus inverted epifluorescence microscope and observed through a $\times 60$ Nomarski optic. An excitation wavelength of $440 \mathrm{~nm}$ was used. Emitted light (510-nm dichroic mirror, 510-560-nm band pass filter) was transmitted through an image intensifier in a CCD camera (Hamamatsu model C-5310, type 11; Hamamatsu Phototonics, Hamamatsu City, Japan). Finally, fluorescence emission intensity was quantified using a computerized system. Briefly, in every single cell of bile ductules incubated with M35 antibody, the fluorescent signal was measured both at the basolateral and at the apical area. Values were corrected for the background fluorescence obtained from a region with no cells and secondly for the background measured in the cellular space. Such background fluorescence was evaluated by means of a thresholding procedure (24). These parameters were calculated in bile ducts of different diameters $(<50 \mu \mathrm{m}$ and $>50 \mu \mathrm{m})$

\section{Immunoperoxidase}

After rinsing in PBS, the fragments of IBDU were preincubated in 0.1-M phosphate buffer, $\mathrm{pH} 7.4$, containing $20 \%$ normal swine serum for $1 \mathrm{~h}$ at room temperature. Subsequently, the sections were rinsed in PBS $(3 \times 10 \mathrm{~min})$ and then incubated with the primary mAb M35 for $2 \mathrm{~h}$ at room temperature. After incubation, sections were washed in PBS $(3 \times 10 \mathrm{~min})$. A rabbit anti-mouse antibody (1:50; DAKOPATTS, Copenhagen, Denmark) was used as the secondary antibody for $30 \mathrm{~min}$ at room temperature. Finally, the sections were incubated with a peroxidase-conjugated swine antibody (1:50; DAKOPATTS), as tertiary antibody, for $30 \mathrm{~min}$ at room temperature. Sections were rinsed again with PBS $(3 \times 10 \mathrm{~min})$ and the reaction product was visualized with diaminobenzidine (DAB) for light and electron microscopy. 
For light microscopy, the developed sections were mounted on glass slides with clearium. Controls were performed by omission of the primary antibody. Microphotographs were taken using an Olympus Vanox photomicroscope equipped with an automatic image analyzer.

\section{Electron microscopy}

For electron microscopy, IBDU were processed as described above for light microscope up to the exposure to DAB. The samples were then fixed with $1 \%$ osmium tetroxide in $0.1-\mathrm{M}$ phosphate buffer, $\mathrm{pH}$ 7.4, followed by dehydration and embedding in Epon/Araldite. Electron microscopy was performed on 60-nm ultrathin sections, with or without staining with lead citrate. The results were evaluated on fragments showing intact epithelium. This meant the presence of a continuous cellular wall surrounding the lumen of bile ducts, intact junctional complexes, no evidence of blebs on the plasma membrane, the identification of basement membrane components along the basolateral aspect of the cell, and intact microvilli on the luminal side.

\section{Solutions}

The composition of solutions used in the study have been described previously in detail $(4,19,25,26)$. Secretin and ACh were made up as a concentrated solution in the appropriate perifusion buffer containing $1 \%(\mathrm{wt} / \mathrm{vol}) \mathrm{BSA}$. These were infused (1:50 vol/vol dilution) into the perifusion fluid, at a rate calculated to produce the required final concentration. Staurosporine, Cyclosporin A, and FK-506 were dissolved in DMSO (stock solution) and then diluted $(1: 10,000, \mathrm{vol} / \mathrm{vol})$ to the required final concentration.

\section{Intracellular $\mathrm{pH}\left(\mathrm{p} \mathrm{H}_{i}\right)$ determination}

$\mathrm{pH}_{\mathrm{i}}$ was measured using a microfluorimetric single-cell method (SPEX-AR-CM-micro system; Spex Industries, Edison, NJ) and BCECF-AM as a fluorescent $\mathrm{pH}_{\mathrm{i}}$ indicator $(4,19,25,26)$. IBDU on glass coverslips were loaded with BCECF-AM $(12 \mu \mathrm{M})$ for $40 \mathrm{~min}$, washed for $10 \mathrm{~min}$ in a BCECF-free medium and transferred into a thermostated perfusion chamber placed on the stage of a Nikon Diaphot inverted microscope. The perfusion media were kept at $37^{\circ} \mathrm{C}$ and gassed both by direct bubbling and an artificial lung. The microscope was connected with a rotating chopper mirror, which rapidly alternated the light generated by a $150 \mathrm{~W}$ xenon lamp between two excitation beams ( 490 and $440 \mathrm{~nm}$ ). Light was attenuated to $0.1 \%$ by heat reflectors and neutral density filters (Omega Optics, Eugene, Oregon). The emitted light was read at $530 \mathrm{~nm}$, integrated by the computer with $500 \mathrm{~ms}$ acquisitions every $1500 \mathrm{~ms}$ and displayed in real time. All measurements for each excitation wavelength were corrected for background fluorescence obtained from dye-free IBDU. Fluorescence intensity exceeded background autofluorescence at least 45 -fold. The 490/440 Fi ratio data were converted to $\mathrm{pH}_{\mathrm{i}}$ values by using the nigericin $(12 \mu \mathrm{M})$ calibration curve technique $(4,19)$. Over the $\mathrm{pH}$ range, 6.4-7.7, fluorescence varied in a linear fashion with $\mathrm{pH}_{\text {out }}$.

\section{Total and intrinsic intracellular buffering power}

The intrinsic buffering power $\left(\beta_{\mathrm{i}}\right)$ was determined at different $\mathrm{pH}_{\mathrm{i}}$ as described $(4,19,25,26)$, by exposing the cells to $30-\mathrm{mM} \mathrm{NH}_{4} \mathrm{Cl}$ in Hepes, $\mathrm{Na}^{+}$-free buffered solutions, and then decreasing the $\mathrm{NH}_{4} \mathrm{Cl}$ concentration by 5 or $10 \mathrm{mM}$ for each step to $0 \mathrm{mM}(n=9)$ from three IBDU preparations. The $\beta_{\mathrm{i}}$ was then calculated from the midpoint change in $\mathrm{pH}_{\mathrm{i}}$ at each step. $\beta_{\mathrm{i}}$ values were then plotted versus $\mathrm{pH}_{\mathrm{i}}$ using a best fit program (Enzfitter). As in other studies $(8,14,15$, 16), a single exponential function provides a better description of the known $\beta_{\mathrm{i}} / \mathrm{pH}_{\mathrm{i}}$ relationships. $\beta_{\mathrm{i}}$ changed from $8.9 \mathrm{mM}$ per $\mathrm{pH}$ unit at $\mathrm{pH}_{\mathrm{i}} 7.7$ to $26.9 \mathrm{mM}$ per $\mathrm{pH}$ unit at $\mathrm{pH}_{\mathrm{i}} 7$ and to $65.1 \mathrm{mM}$ per $\mathrm{pH}$ unit at $\mathrm{pH}_{\mathrm{i}}$ 6.5. For each experimental protocol, $\beta_{\mathrm{i}}$ was obtained from the relative $\beta_{\mathrm{i}} / \mathrm{pH}_{\mathrm{i}}$ curves as estimated above, for that $\mathrm{pH}_{\mathrm{i}}$ at which $\delta \mathrm{pH}_{\mathrm{i}} /$ $\delta \mathrm{t}$ was measured. $\mathrm{H}^{+}$fluxes were then calculated by the formula: $\mathrm{H}^{+}$ fluxes $=\beta_{\mathrm{i}} \times \delta \mathrm{pH}_{\mathrm{i}} / \mathrm{min}$. In this formula, $\beta_{\mathrm{tot}}$ substituted for $\beta_{\mathrm{i}}$ when experiments were performed in the presence of bicarbonate. $\beta_{\text {tot }}$ was calculated from the formula $\beta_{\text {tot }}=\beta_{\mathrm{i}}+2.303 \times\left[\mathrm{HCO}_{3}{ }^{-}\right]_{\mathrm{i}}$ where in- tracellular $\left[\mathrm{HCO}_{3}^{-}\right]$is derived from the Henderson-Hasselbach equation.

\section{$\mathrm{Cl}^{-} / \mathrm{HCO}_{3}^{-}$exchanger activity}

The activity of the $\mathrm{Cl}^{-} / \mathrm{HCO}_{3}{ }^{-}$exchanger was evaluated $(4,19,25,26)$ by measuring the net $\mathrm{pH}_{\mathrm{i}}$ increase and the maximal rate of alkalinization after acute $\mathrm{Cl}^{-}$removal from the perfusing solution (equimolar substitution with $\mathrm{Na}^{+}$-gluconate), as well as the maximal rate of $\mathrm{pH}_{\mathrm{i}}$ recovery after $\mathrm{Cl}^{-}$readmission.

\section{Purification and phenotypic characterization of cholangiocytes} from rat liver

After standard collagenase perfusion, a mixed nonparenchymal cell fraction $(\sim 50 \%$ pure by $\gamma$-glutamyltranspeptidase) was isolated from portal tract residue as described previously (27-31). Briefly, after a series of enzymatic digestions, virtually pure preparations of cholangiocytes were purified by immunoaffinity separation (27-31) using an antibody raised against an antigen expressed by all intrahepatic cholangiocytes (27). Cell number and viability was assessed by standard trypan blue exclusion. Purity was assessed by histochemistry for $\gamma$-glutamyltranspeptidase (32), a specific marker of cholangiocytes in rat liver $(3,27,33)$. The degree of contamination of cholangiocyte preparations was determined by positive identification for hepatocytes, endothelial, and mesenchymal cells as described previously (34).

\section{In vitro molecular analysis}

The genetic expression of selected messages, i.e., M3 muscarinic ACh receptor and glyceraldehyde-3-phosphate dehydrogenase (GAPDH), the housekeeping gene $(30,31)$, was measured by reverse transcriptase PCR (RT-PCR) using 5 ng of Poly $\mathrm{A}^{+}$mRNA extracted from pure preparations of cholangiocytes by a commercially available kit (Invitrogen Corp.) according to the instructions supplied by the vendor. For the molecular analysis of M3 muscarinic ACh receptor standard RT-PCR conditions were used: 35 step cycles, $30 \mathrm{~s}$ at $94^{\circ} \mathrm{C}$, $30 \mathrm{~s}$ at $55^{\circ} \mathrm{C}$, and $45 \mathrm{~s}$ at $72^{\circ} \mathrm{C}$. Specific oligonucleotide primers for the M3 muscarinic receptor gene (sense 5'-GAAGGAGAGGCATACCGCTAAAC-3' and antisense 5'-AGAACCAAGAGTCAAATCCACGCTATAG-3', expected fragment length $375 \mathrm{bp}$ ) were based on the rat M3 muscarinic ACh receptor sequence $(35,36)$. For the molecular analysis of the M3 muscarinic ACh receptor genes, we used brain and yeast transfer RNA as positive and negative controls, respectively.

For the molecular analysis of the M1 muscarinic ACh receptor, specific oligonucleotide primers were designed from the coding region of the M1 rat muscarinic receptor (35). The $5^{\prime}$ sequence of the primers started at base pair 997 (5'-GGAGTCCCTCACATCCTCCGA-3') and the $3^{\prime}$ sequence started at base pair 1471 (5'-CGCCAGCGCCTCTTGTCCCAG-3') with an expected fragment length of $474 \mathrm{bp}$. For the molecular analysis of the M1 muscarinic ACh receptor in pure preparations of cholangiocytes, we used the same RTPCR conditions as Elsing et al. (37): 30 cycles of denaturation at $95^{\circ} \mathrm{C}$ for $1 \mathrm{~min}$ annealing at $65^{\circ} \mathrm{C}$ for $1 \mathrm{~min}$, and extension at $72^{\circ} \mathrm{C}$ for $1 \mathrm{~min}$. Rat brain and yeast transfer RNA were used as positive and negative controls, respectively.

Specific primers for the GAPDH gene (sense 5'-GTGACTTCAACAGCAACTCCCATTC-3' and antisense 5'-GTTATGGGGTCTGGGATGGAATTGTG-3', expected fragment length 294 bp) were based on the rat GAPDH sequence (38). Rat kidney and yeast transfer RNA were the positive and negative controls for the GAPDH gene, respectively.

\section{Intracellular cAMP levels}

Basal- and agonist-induced intracellular cAMP levels in pure preparations of isolated cholangiocytes were measured at $22^{\circ} \mathrm{C}$, as described previously by us $(7,29,31)$ and others (39). After isolation, cholangiocytes were incubated for $2 \mathrm{~h}$ at $37^{\circ} \mathrm{C}$ to restore secretin receptors damaged by treatment with proteolytic enzymes (39) and stimulated for $5 \mathrm{~min}$ at $22^{\circ} \mathrm{C}$ in the presence of $0.2 \%$ BSA with $(a)$ secretin $(50 \mathrm{nM}) ;(b)$ ACh $(10 \mu \mathrm{M}) ;(c)$ secretin $(50 \mathrm{nM})$ plus ACh 
$(10 \mu \mathrm{M}) ;(d)$ carbachol $(100 \mu \mathrm{M}) ;(e)$ secretin $50 \mathrm{nM}$ plus carbachol $(100 \mu \mathrm{M})$; or $(f) 0.2 \%$ BSA. In a separate set of experiments, aliquots of the same cholangiocyte preparations were treated with $100-\mathrm{nM}$ cyclosporin A or FK-506, two inhibitors of calcineurin (40, 41), for 60 $\min$ at $37^{\circ} \mathrm{C}$ before being exposed to secretin $(50 \mathrm{nM})$ or secretin $(50$ $\mathrm{nM})$ plus ACh $(10 \mu \mathrm{M})$ for $5 \mathrm{~min}$ at $22^{\circ} \mathrm{C}$. After extraction with ethanol, cAMP levels were determined by a commercially available kit (Amersham Corp.) according to the vendor's instructions. Intracellular cAMP levels were expressed as femtomol per $10^{5}$ cells.

\section{Statistical analysis}

Data are presented as arithmetic means \pm SEM unless otherwise indicated. Statistical analysis was conducted using the paired or unpaired Student's $t$ test as appropriate or the ANOVA when more than two groups were compared.

\section{Results}

Immunofluorescence and immunoelectron microscopy detection of ACh receptors in IBDU. Exposure to the anti-mAChR $\mathrm{mAb}$ M35 yielded a specific reaction product on normal rat cholangiocytes, as shown by both indirect immunofluorescence (Fig. 1), light, and immunoelectron microscopy (Fig. 2).

Under the light microscope, M35 immunoreactivity stained the membrane of the cholangiocytes. The immunofluorescence was distributed at the periphery of the cytoplasm with a preferential localization in the basolateral area of cholangiocytes (Fig. 1) as shown by a basolateral immunofluorescence total value higher than the apical value $(8.16 \pm 1.2$ versus $3.63 \pm 1.02$ fluorescence units; $P<0.01)$. No differences were found between ducts of diameter $<50 \mu \mathrm{m}$ and ducts of diame- ter $>50 \mu \mathrm{m}$ (basolateral fluorescence $8.5 \pm 1.2$ and $7.99 \pm 1.1$ respectively, and apical fluorescence $3.1 \pm 1.1$ and $2.61 \pm 0.2$ fluorescence units). In sample preincubated with $40 \mathrm{nM}$ of 4-DAMP, for $20 \mathrm{~min}$ at $37^{\circ} \mathrm{C}$, and exposed to the anti-mAChR M35 antibody, no staining was evident at the level of cholangiocytes. At the ultrastructural level there was evidence of deposition of a dense reaction product along the basolateral membranes, with a preferential localization at the level of invaginations of the cell membrane (Fig. $2 a$ ). The morphological features of these invaginations were often reminiscent of coated pits, suggesting receptor-mediated endocytosis (Fig. $2 a$ ).

When different sections were exposed to the M2 muscarinic ACh receptor monoclonal antibody, a specific staining was evident in endothelial cells of the vascular wall near to bile ducts. In contrast, no staining appeared at the level of plasmamembrane of biliary epithelial cells.

Effect of ACh on basal and secretin-stimulated $\mathrm{Cl}^{-} / \mathrm{HCO}_{3}{ }^{-}$ exchanger activity. ACh $(10 \mu \mathrm{M})$ showed no measurable effect on basal $\mathrm{pH}_{\mathrm{i}}$ of IBDU cultured in bicarbonate rich medium $(\alpha \mathrm{MEM})$ and perfused with $\mathrm{KRB}(n=7)$. To evaluate the effect of $\mathrm{ACh}$ on the basal activity of the $\mathrm{Cl}^{-} / \mathrm{HCO}_{3}{ }^{-}$exchanger, two sequential $\mathrm{Cl}^{-}$removal/readmission maneuvers were performed, the second during superfusion with ACh (10 $\mu \mathrm{M}, n=25$; Table I, Fig. 3). The net $\mathrm{pH}_{\mathrm{i}}$ increase and the maximal rate of alkalinization after $\mathrm{Cl}^{-}$removal as well as the maximal rate of $\mathrm{pH}_{\mathrm{i}}$ recovery after $\mathrm{Cl}^{-}$readmission did not show any significant difference either in the presence (second maneuver) or absence (first maneuver) of $\mathrm{ACh}\left(\mathrm{Cl}^{-}\right.$removal $=$ $0.153 \pm 0.015$ versus $0.141 \pm 0.014 \mathrm{pHU} / \mathrm{min}, \mathrm{H}^{+}$flux $=9.13 \pm 0.932$ versus $8.41 \pm 0.890 \mathrm{mM} / \mathrm{min} ; \mathrm{Cl}^{-}$readmission $=0.198 \pm 0.016$

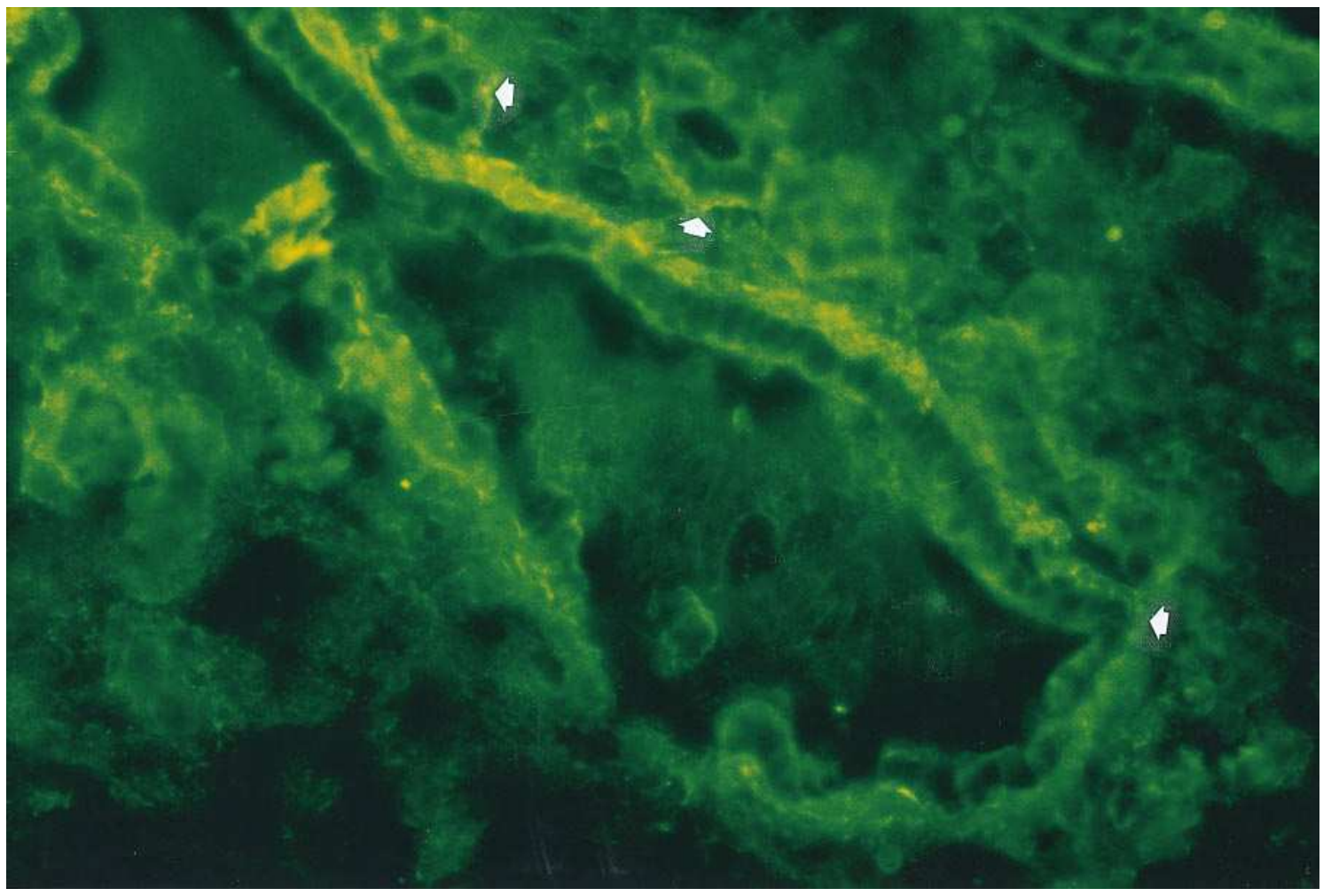

Figure 1. Immunofluorescence of IBDU isolated from rat liver and exposed to muscarinic ACh receptor monoclonal antibody (M35). Fluorescent signal was preferentially localized at the basolateral area of the biliary epithelium (arrowheads). Differences between small ( 3 to 10 cells) and large ducts (20 to 30 cells) were not evident. $\times 60$. 

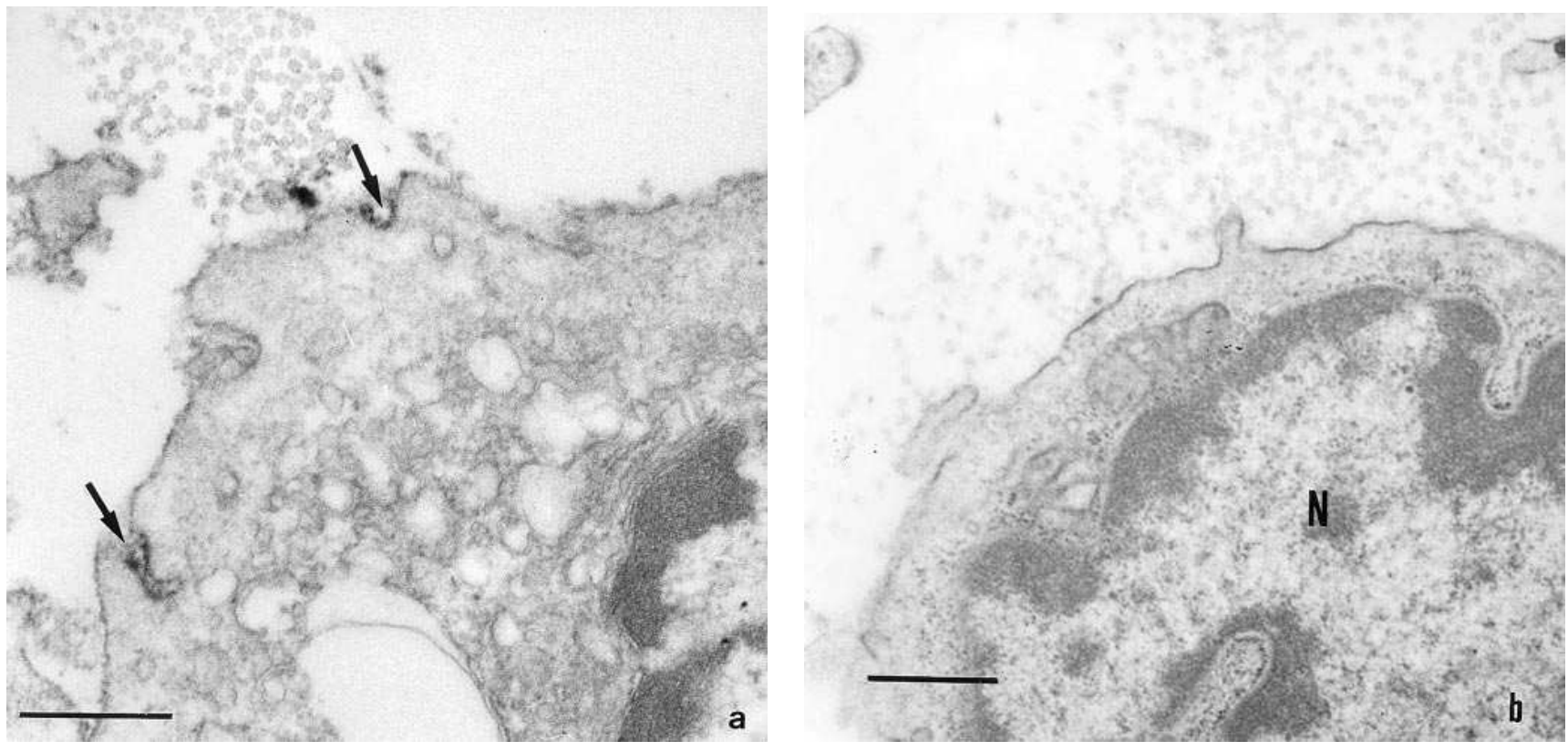

Figure 2. Immunoelectron microscopy of freshly isolated bile ducts from rat liver. (a) Results with muscarinic ACh receptor monoclonal antibody (M35) and peroxidase conjugated secondary antibody. There is evidence of localization of dense reaction product at the level of invaginations of the cell membrane, exhibiting, at times, the configuration of coated pits (arrows). (b) Results without primary antibody followed by peroxidase-conjugated secondary antibody. No reaction product can be seen along the cell membrane. $N$, nucleus; bar $=0.5 \mu \mathrm{m}$.

versus $0.184 \pm 0.017 \mathrm{pHU} / \mathrm{min}, \mathrm{H}^{+}$flux $=12.24 \pm 1.095$ versus $11.32 \pm 1.25 \mathrm{mM} / \mathrm{min})$. These experiments indicate that $\mathrm{ACh}$ has no effect on the basal activity of the $\mathrm{Cl}^{-} / \mathrm{HCO}_{3}{ }^{-}$exchanger.

To evaluate whether ACh could influence the secretin stimulation of the $\mathrm{Cl}^{-} / \mathrm{HCO}_{3}{ }^{-}$exchanger activity, two sequential $\mathrm{Cl}^{-}$removal/readmission maneuvers were performed, the second during exposure to ACh $(10 \mu \mathrm{M})+\operatorname{secretin}(50 \mathrm{nM})$ (Fig. 3, Table I). Findings were compared with experiments where secretin alone was administered in correspondence with the second $\mathrm{Cl}^{-}$removal/readmission maneuver (Fig. 3, Table I). Secretin alone (second maneuver) significantly $(P<0.02)$ enhanced the maximal rate of alkalinization after $\mathrm{Cl}^{-}$removal as well as the maximal rate of $\mathrm{pH}_{\mathrm{i}}$ recovery after $\mathrm{Cl}^{-}$readmission compared with correspondent parameters measured in the absence of this hormone. This confirms $(4,19)$ a secretin stimulation of the $\mathrm{Cl}^{-} / \mathrm{HCO}_{3}{ }^{-}$exchanger activity. When IBDU were exposed to secretin plus $\mathrm{ACh}, \mathrm{ACh}$ induced an additional stimulation of the $\mathrm{Cl}^{-} / \mathrm{HCO}_{3}{ }^{-}$exchanger activity compared to that induced by secretin alone. In fact, the maximal rate of alkalinization after $\mathrm{Cl}^{-}$removal $(0.292 \pm 0.022 \mathrm{pHU} /$ $\min , \mathrm{H}^{+}$flux $=17.42 \pm 1.692 \mathrm{mM} / \mathrm{min}$ ) and the maximal rate of $\mathrm{pH}_{\mathrm{i}}$ recovery after $\mathrm{Cl}^{-}$readmission $(0.325 \pm 0.023 \mathrm{pHU} / \mathrm{min}$, $\mathrm{H}^{+}$flux $=20.33 \pm 1.490 \mathrm{mM} / \mathrm{min}$ ) measured during exposure to secretin plus ACh were significantly $(P<0.05)$ higher than correspondent parameters measured during exposure to secretin alone (Table I, Fig. 3). Parameters measured after $\mathrm{Cl}^{-}$removal showed that the $\mathrm{Cl}^{-} / \mathrm{HCO}_{3}{ }^{-}$exchanger activity is stimulated $63 \%$ by secretin alone and $118 \%$ by secretin plus ACh. These findings indicate that $\mathrm{ACh}$ enhances the stimulatory effect of secretin on $\mathrm{Cl}^{-} / \mathrm{HCO}_{3}{ }^{-}$exchanger activity in IBDU.

Effect of 4-DAMP on ACh plus secretin-induced stimulation of $\mathrm{Cl}^{-} / \mathrm{HCO}_{3}^{-}$exchanger activity. IBDU were preincubated (15-20 $\mathrm{min})$ and perfused with 40-nM 4-DAMP, a mus-

Table I. Effect of ACh, Secretin, and ACh plus Secretin on $\mathrm{Cl}^{-} / \mathrm{HCO}_{3}{ }^{-}$Exchanger Activity in IBDU

\begin{tabular}{|c|c|c|c|c|c|c|}
\hline & Control & $\mathrm{ACh}$ & Control & Secretin & Control & ACh plus secretin \\
\hline & \multicolumn{2}{|c|}{$n=25$} & \multicolumn{2}{|c|}{$n=19$} & \multicolumn{2}{|c|}{$n=29$} \\
\hline Basal $\mathrm{pH}_{\mathrm{i}}$ & $7.18 \pm 0.012$ & $7.19 \pm 0.012$ & $7.21 \pm 0.014$ & $7.20 \pm 0.015$ & $7.19 \pm 0.012$ & $7.19 \pm 0.013$ \\
\hline \multicolumn{7}{|l|}{$\mathrm{Cl}^{-}$removal } \\
\hline Delta $\mathrm{pH}_{\mathrm{i}}$ & $0.24 \pm 0.011$ & $0.25 \pm 0.010$ & $0.23 \pm 0.012$ & $0.28 \pm 0.016$ & $0.24 \pm 0.011$ & $0.30 \pm 0.017$ \\
\hline $\mathrm{pH}, \max \mathrm{U} / \min$ & $0.141 \pm 0.014$ & $0.153 \pm 0.015$ & $0.129 \pm 0.011$ & $0.210 \pm 0.018 *$ & $0.134 \pm 0.012$ & $0.292 \pm 0.022 * \S$ \\
\hline $\mathrm{H}^{+}$flux, $\mathrm{mM} / \mathrm{min}$ & $8.41 \pm 0.890$ & $9.13 \pm 0.932$ & $7.70 \pm 0.738$ & $12.53 \pm 1.096^{*}$ & $8.14 \pm 0.804$ & $17.42 \pm 1.692^{* \ddagger}$ \\
\hline \multicolumn{7}{|l|}{$\mathrm{Cl}^{-}$readmission } \\
\hline $\mathrm{pH}, \max \mathrm{U} / \min$ & $0.184 \pm 0.017$ & $0.198 \pm 0.016$ & $0.174 \pm 0.015$ & $0.256 \pm 0.020 *$ & $0.182 \pm 0.014$ & $0.325 \pm 0.023^{* \ddagger}$ \\
\hline $\mathrm{H}^{+}$flux, $\mathrm{mM} / \mathrm{min}$ & $11.32 \pm 1.25$ & $12.24 \pm 1.095$ & $10.75 \pm 1.025$ & $15.92 \pm 1.481^{*}$ & $11.22 \pm 1.123$ & $20.33 \pm 1.490^{* \ddagger}$ \\
\hline
\end{tabular}

Two sequential $\mathrm{Cl}^{-}$removal/readmission maneuvers were performed, the second during exposure to $10-\mu \mathrm{M} \mathrm{ACh}, 50$-nM secretin, or ACh plus secretin. Data are mean \pm SEM. $* P<0.02$ versus control values. ${ }^{\ddagger} P<0.05$ versus secretin alone. ${ }^{\S} P<0.03$ versus secretin alone. 


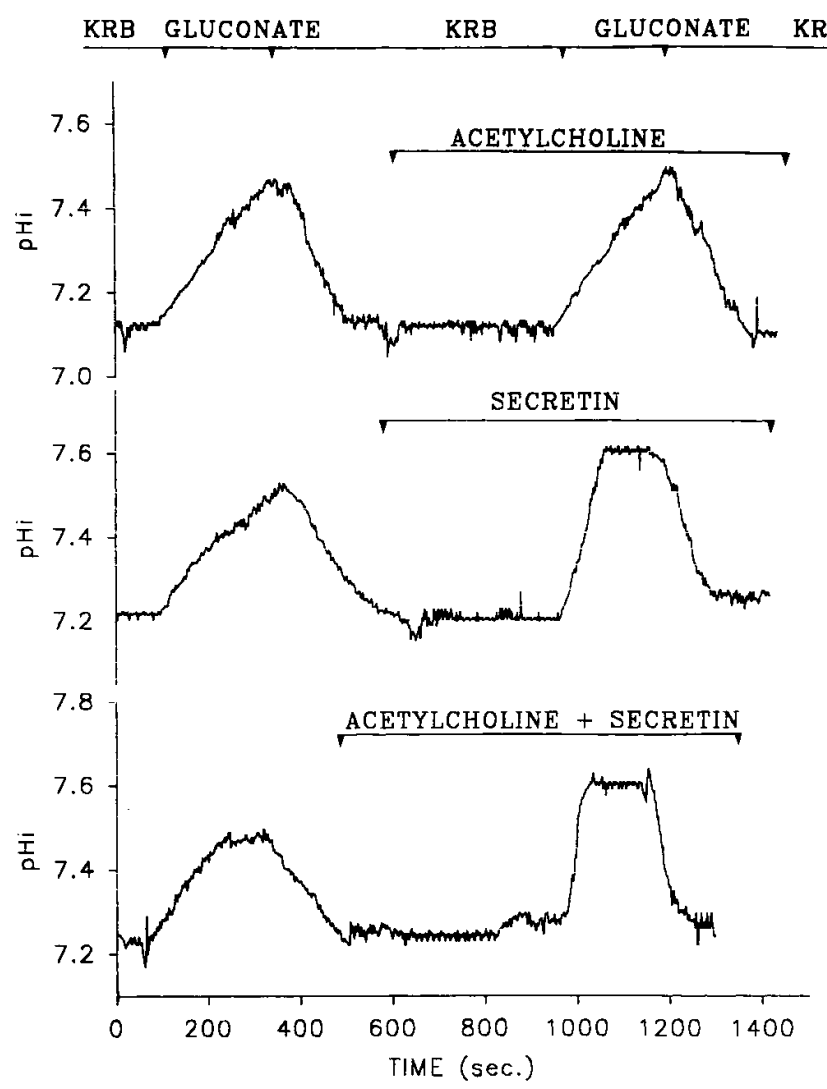

Figure 3. Effect of ACh on basal- and secretin-stimulated $\mathrm{Cl}^{-}$/ $\mathrm{HCO}_{3}{ }^{-}$exchanger activity in IBDU. The $\mathrm{Cl}^{-} / \mathrm{HCO}_{3}{ }^{-}$exchanger activity was evaluated by measuring the maximal rate of alkalinization after $\mathrm{Cl}^{-}$removal (equimolar substitution with gluconate) and the maximal rate of $\mathrm{pH}_{\mathrm{i}}$ recovery after $\mathrm{Cl}^{-}$readmission. Two sequential $\mathrm{Cl}^{-}$removal/readmission maneuvers were performed, the second during superfusion with $10-\mu \mathrm{M}$ ACh (top, $n=25)$, 50-nM secretin (middle, $n=19$ ) or ACh plus secretin (bottom, $n=29$ ). ACh alone showed no effect on the maximal rate of alkalinization after $\mathrm{Cl}^{-}$removal nor on the maximal rate of $\mathrm{pH}_{\mathrm{i}}$ recovery after $\mathrm{Cl}^{-}$readmission in comparison with correspondent control parameters (first $\mathrm{Cl}^{-}$removal/readmission maneuver). Secretin alone increased both the rate carinic receptor antagonist with a high affinity for M3 subtype receptor (42-46). Two sequential $\mathrm{Cl}^{-}$removal/readmission maneuvers were then performed, the second during exposure to $50-\mathrm{nM}$ secretin or $50-\mathrm{nM}$ secretin plus $10-\mu \mathrm{M}$ ACh. Findings were compared with similar paired experiments performed in the absence of 4-DAMP (Fig. 4, Table II).

4-DAMP showed no effect on the secretin stimulation of the $\mathrm{Cl}^{-} / \mathrm{HCO}_{3}{ }^{-}$exchanger activity. The maximal rate of alkalinization after $\mathrm{Cl}^{-}$removal and the maximal rate of $\mathrm{pH}_{\mathrm{i}}$ recovery after $\mathrm{Cl}^{-}$readmission measured during exposure to secretin (second maneuver) were similar both in the absence and presence of 4-DAMP (Fig. 4).

In contrast, in the presence of 4-DAMP, ACh failed to increase the secretin stimulatory effect on the activity of $\mathrm{Cl}^{-}$/ $\mathrm{HCO}_{3}{ }^{-}$exchanger. In fact, the maximal rate of alkalinization after $\mathrm{Cl}^{-}$removal and the maximal rate of $\mathrm{pH}_{\mathrm{i}}$ recovery after $\mathrm{Cl}^{-}$readmission measured during exposure to secretin plus ACh (second maneuver) were significantly $(P<0.03)$ lower in the presence than in the absence of 4-DAMP. From the parameters measured after $\mathrm{Cl}^{-}$removal, the $\mathrm{Cl}^{-} / \mathrm{HCO}_{3}^{-}$exchanger activity appears to be stimulated $98 \%$ by secretin plus $\mathrm{ACh}$ in the absence of 4-DAMP and $55 \%$ in the presence of 4-DAMP.

Effect of the intracellular $\mathrm{Ca}^{2+}$ chelator, BAPTA/AM, on ACh plus secretin-induced stimulation of $\mathrm{Cl}^{-} / \mathrm{HCO}_{3}^{-}$exchanger activity. IBDU were preincubated (45 $\mathrm{min})$ and perfused with $50 \mu \mathrm{M}$ of the intracellular $\mathrm{Ca}^{2+}$ chelator, BAPTA/ AM. Thereafter, two sequential $\mathrm{Cl}^{-}$removal/readmission maneuvers were performed, the second during exposure to $50-\mathrm{nM}$ secretin $(n=12)$ or $50-n M$ secretin plus $10-\mu \mathrm{M}$ ACh $(n=19)$.

of intracellular alkalinization after $\mathrm{Cl}^{-}$removal and the rate of $\mathrm{pH}_{\mathrm{i}}$ recovery after $\mathrm{Cl}^{-}$readmission in comparison with correspondent control parameters (first $\mathrm{Cl}^{-}$removal/readmission maneuver). Exposure to ACh plus secretin (bottom, second maneuver), induced an additional increase in both the rate of intracellular alkalinization after $\mathrm{Cl}^{-}$removal and the rate of $\mathrm{pH}_{\mathrm{i}}$ recovery after $\mathrm{Cl}^{-}$readmission, compared with correspondent parameters measured during exposure to secretin alone (middle, second $\mathrm{Cl}^{-}$removal/readmission maneuver).

Table II. Effect of 4-DAMP on Secretin and ACh plus Secretin Stimulation of the $\mathrm{Cl}^{-} / \mathrm{HCO}_{3}{ }^{-}$Exchanger Activity in IBDU

\begin{tabular}{|c|c|c|c|c|c|c|}
\hline & Control & Secretin & Control & $\begin{array}{l}\text { ACh plus } \\
\text { secretin }\end{array}$ & 4-DAMP & $\begin{array}{c}\text { 4-DAMP + } \\
\text { secretin + ACh }\end{array}$ \\
\hline & \multicolumn{2}{|c|}{$n=10$} & \multicolumn{2}{|c|}{$n=16$} & \multicolumn{2}{|c|}{$n=16$} \\
\hline Basal $\mathrm{pH}_{\mathrm{i}}$ & $7.22 \pm 0.018$ & $7.21 \pm 0.018$ & $7.20 \pm 0.013$ & $7.21 \pm 0.013$ & $7.18 \pm 0.011$ & $7.17 \pm 0.012$ \\
\hline \multicolumn{7}{|l|}{$\mathrm{Cl}^{-}$removal } \\
\hline Delta $\mathrm{pH}_{\mathrm{i}}$ & $0.24 \pm 0.020$ & $0.29 \pm 0.021$ & $0.22 \pm 0.012$ & $0.30 \pm 0.019$ & $0.25 \pm 0.011$ & $0.32 \pm 0.016$ \\
\hline $\mathrm{pH}, \max \mathrm{U} / \mathrm{min}$ & $0.127 \pm 0.016$ & $0.192 \pm 0.022 *$ & $0.143 \pm 0.013$ & $0.283 \pm 0.016 * \S$ & $0.131 \pm 0.012$ & $0.203 \pm 0.018^{* \neq}$ \\
\hline $\mathrm{H}^{+}$flux, $\mathrm{mM} / \mathrm{min}$ & $7.54 \pm 0.940$ & $11.33 \pm 1.402 *$ & $8.04 \pm 0.790$ & $16.23 \pm 1.012 * \S$ & $7.85 \pm 0.768$ & $12.08 \pm 1.283^{* \neq}$ \\
\hline \multicolumn{7}{|l|}{$\mathrm{Cl}^{-}$readmission } \\
\hline $\mathrm{pH}, \max \mathrm{U} / \min$ & $0.179 \pm 0.017$ & $0.261 \pm 0.020^{*}$ & $0.199 \pm 0.014$ & $0.333 \pm 0.024 * \S$ & $0.169 \pm 0.013$ & $0.249 \pm 0.019^{* \ddagger}$ \\
\hline $\mathrm{H}^{+}$flux, $\mathrm{mM} / \mathrm{min}$ & $10.55 \pm 1.031$ & $15.131 \pm 1.499 *$ & $11.960 \pm 1.011$ & $20.67 \pm 1.270 * \S$ & $10.22 \pm 1.002$ & $15.360 \pm 1.131^{* \neq}$ \\
\hline
\end{tabular}

Two sequential $\mathrm{Cl}^{-}$removal/readmission maneuvers were performed, the second during exposure to secretin $(50 \mathrm{nM})$ or $\mathrm{ACh}(10 \mu \mathrm{M})$ plus secretin in controls or in IBDU pretreated and perfused with 4-DAMP, a muscarinic acetylcholine receptor antagonist with high affinity for M3 receptors. Data were compared with experiments performed in the absence of 4-DAMP. $* P<0.02$ versus control values. ${ }^{\ddagger} P<0.03$ versus ACh plus secretin. ${ }^{\S} P<0.05$ versus secretin alone. Data are mean \pm SEM. 

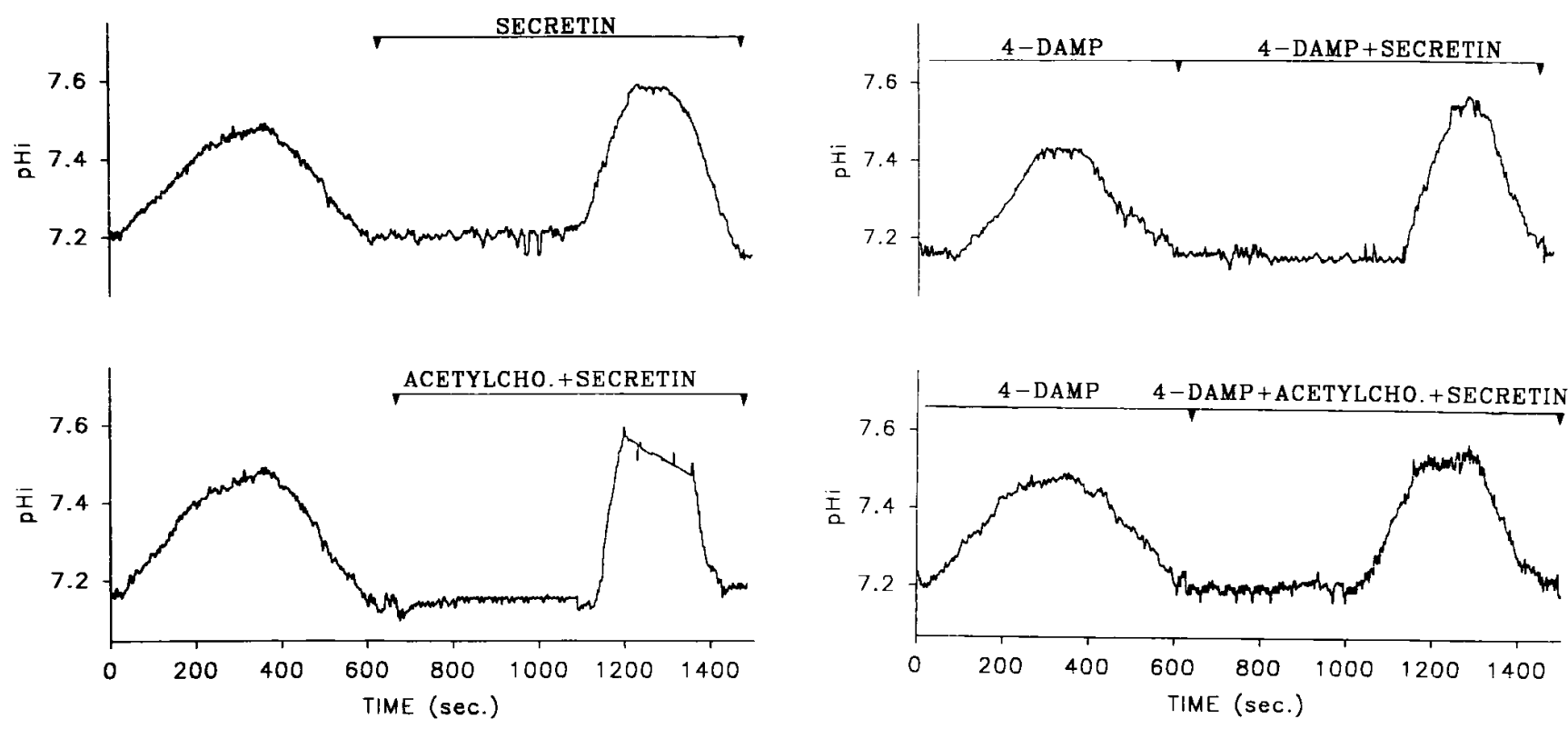

Figure 4. Effect of 4-DAMP, a muscarinic receptor antagonist with high affinity for M3 subtype receptor, on secretin and secretin plus ACh induced stimulation of the $\mathrm{Cl}^{-} / \mathrm{HCO}_{3}{ }^{-}$exchanger activity in IBDU. Two sequential $\mathrm{Cl}^{-}$removal/readmission maneuvers were performed, the second during superfusion with 50-nM secretin or 10- $\mu \mathrm{M}$ ACh plus 50-nM secretin. Findings were compared with similar paired experiments performed in IBDU, preincubated, and perfused with 40-nM 4-DAMP. The maximal rate of alkalinization after $\mathrm{Cl}^{-}$removal and the maximal rate of $\mathrm{pH}_{\mathrm{i}}$ recovery after $\mathrm{Cl}^{-}$readmission measured during exposure to secretin (second maneuver, top) were similar in the absence (left) or presence of 4-DAMP (right), indicating that 4-DAMP has no effect on the secretin stimulation of the $\mathrm{Cl}^{-} / \mathrm{HCO}_{3}{ }^{-}$exchanger activity. In contrast, in the presence of 4-DAMP, ACh failed to increase the secretin stimulatory effect on the activity of $\mathrm{Cl}^{-} / \mathrm{HCO}_{3}{ }^{-}$exchanger.

Findings were compared with similar paired experiments performed in the absence of BAPTA/AM (Table III).

BAPTA/AM showed no effect on the secretin stimulation of the $\mathrm{Cl}^{-} / \mathrm{HCO}_{3}{ }^{-}$exchanger. In fact, the maximal rate of alkalinization after $\mathrm{Cl}^{-}$removal and the maximal rate of $\mathrm{pH}_{\mathrm{i}}$ recovery after $\mathrm{Cl}^{-}$readmission measured during exposure to secretin (second maneuver) were similar either in the absence or presence of BAPTA/AM. From the parameters measured after $\mathrm{Cl}^{-}$removal, the $\mathrm{Cl}^{-} / \mathrm{HCO}_{3}{ }^{-}$exchanger activity appears to be stimulated $64 \%$ by secretin in the absence of BAPTA/AM and $65 \%$ in the presence of BAPTA/AM. In contrast, chelation of intracellular $\mathrm{Ca}^{2+}$ with BAPTA/AM completely inhibited the effect of $\mathrm{ACh}$ on the secretin stimulation of $\mathrm{Cl}^{-}$/ $\mathrm{HCO}_{3}{ }^{-}$exchanger activity. In fact, the maximal rate of alkalinization after $\mathrm{Cl}^{-}$removal and the maximal rate of $\mathrm{pH}_{\mathrm{i}}$ recovery after $\mathrm{Cl}^{-}$readmission measured during exposure to secretin plus ACh (second maneuver) were significantly lower $(P<$ $0.03)$ in the presence than in the absence of BAPTA/AM. The stimulation of the $\mathrm{Cl}^{-} / \mathrm{HCO}_{3}{ }^{-}$exchanger activity by secretin plus ACh decreased from $109 \%$ in control conditions to $62 \%$ in the presence of BAPTA/AM.

Effect of staurosporine on ACh plus secretin-induced stimulation of $\mathrm{Cl}^{-} / \mathrm{HCO}_{3}{ }^{-}$exchanger activity. Since ACh increases cytosolic $\mathrm{Ca}^{2+}$ in IBDU (18), we evaluated whether protein kinase $\mathrm{C}$ (PKC) could be involved in the ACh plus secretininduced stimulation of $\mathrm{Cl}^{-} / \mathrm{HCO}_{3}{ }^{-}$exchanger activity, by using the PKC inhibitor staurosporine. IBDU exposed to $0.1-\mu \mathrm{M}$ staurosporine were submitted to two sequential $\mathrm{Cl}^{-}$removal/ readmission maneuvers, the second during administration of secretin plus ACh (Table IV). Findings were compared with similar paired experiments performed in the absence of staurosporine. The maximal rate of alkalinization after $\mathrm{Cl}^{-}$removal and the maximal rate of $\mathrm{pH}_{\mathrm{i}}$ recovery after $\mathrm{Cl}^{-}$readmission measured during exposure to secretin plus ACh were similar both in the absence and presence of staurosporine. From the parameters measured after $\mathrm{Cl}^{-}$removal, the $\mathrm{Cl}^{-} / \mathrm{HCO}_{3}{ }^{-}$exchanger activity appears to be stimulated $120 \%$ by secretin plus ACh in the absence of staurosporine and $123 \%$ in the presence of staurosporine. Staurosporine alone (Table IV) did not influence $\mathrm{pH}_{\mathrm{i}}$ changes induced by acute $\mathrm{Cl}^{-}$removal/readmission that were similar with respect to control values (first maneuver in untreated IBDU), indicating that staurosporine alone does not affect the activity of the $\mathrm{Cl}^{-} / \mathrm{HCO}_{3}{ }^{-}$exchanger. These experiments demonstrate that blocking PKC with staurosporine failed to influence the stimulatory effect of ACh plus secretin on the $\mathrm{Cl}^{-} / \mathrm{HCO}_{3}{ }^{-}$exchanger. Thus, ACh enhancement of the secretin stimulation of $\mathrm{Cl}^{-} / \mathrm{HCO}_{3}{ }^{-}$exchanger activity occurs by a PKC insensitive mechanism.

Effect of the calcineurin inhibitors, FK-506 and cyclosporin A on ACh plus secretin-induced stimulation of $\mathrm{Cl}^{-} / \mathrm{HCO}_{3}^{-}$exchanger activity. IBDU, preincubated (30-45 min) with $100-\mathrm{nM}$ FK-506, were submitted to two sequential $\mathrm{Cl}^{-}$removal/readmission maneuvers, the second during administration of secretin (Fig. 5, Table V) or secretin plus ACh (Fig. 5, Table V). Findings were compared with similar paired experiments performed in the absence of FK-506. The maximal rate of alkalin- 


\begin{tabular}{|c|c|c|c|c|}
\hline & Control & Secretin & BAPTA/AM & BAPTA/AM plus secretin \\
\hline & \multicolumn{2}{|c|}{$n=12$} & \multicolumn{2}{|c|}{$n=12$} \\
\hline Basal $\mathrm{pH}_{\mathrm{i}}$ & $7.19 \pm 0.014$ & $7.21 \pm 0.015$ & $7.23 \pm 0.014$ & $7.20 \pm 0.015$ \\
\hline \multicolumn{5}{|l|}{$\mathrm{Cl}^{-}$removal } \\
\hline Delta $\mathrm{pH}_{\mathrm{i}}$ & $0.22 \pm 0.017$ & $0.28 \pm 0.018$ & $0.25 \pm 0.015$ & $0.29 \pm 0.016$ \\
\hline $\mathrm{pH}, \max \mathrm{U} / \mathrm{min}$ & $0.121 \pm 0.014$ & $0.199 \pm 0.017 *$ & $0.125 \pm 0.016$ & $0.206 \pm 0.018^{*}$ \\
\hline $\mathrm{H}^{+}$flux, $\mathrm{mM} / \mathrm{min}$ & $7.34 \pm 0.780$ & $11.93 \pm 1.093^{*}$ & $7.49 \pm 0.668$ & $12.18 \pm 1.069^{*}$ \\
\hline \multicolumn{5}{|l|}{$\mathrm{Cl}^{-}$readmission } \\
\hline $\mathrm{pH}, \max \mathrm{U} / \mathrm{min}$ & $0.173 \pm 0.017$ & $0.252 \pm 0.021 *$ & $0.180 \pm 0.019$ & $0.283 \pm 0.022 *$ \\
\hline \multirow[t]{3}{*}{$\mathrm{H}^{+}$flux, $\mathrm{mM} / \min$} & $11.06 \pm 1.111$ & $15.74 \pm 1.334 *$ & $10.99 \pm 1.114$ & $17.19 \pm 1.631^{*}$ \\
\hline & Control & ACh plus secretin & BAPTA/AM & $\begin{array}{l}\text { BAPTA/AM + } \\
\text { secretin }+ \text { ACh }\end{array}$ \\
\hline & \multicolumn{2}{|c|}{$n=19$} & \multicolumn{2}{|c|}{$n=19$} \\
\hline Basal $\mathrm{pH}_{\mathrm{i}}$ & $7.18 \pm 0.011$ & $7.19 \pm 0.011$ & $7.22 \pm 0.011$ & $7.20 \pm 0.012$ \\
\hline \multicolumn{5}{|l|}{$\mathrm{Cl}^{-}$removal } \\
\hline Delta $\mathrm{pH}_{\mathrm{i}}$ & $0.24 \pm 0.014$ & $0.28 \pm 0.015$ & $0.25 \pm 0.016$ & $0.32 \pm 0.017$ \\
\hline $\mathrm{pH}, \max \mathrm{U} / \min$ & $0.129 \pm 0.011$ & $0.270 \pm 0.016^{* \S}$ & $0.133 \pm 0.013$ & $0.215 \pm 0.016^{* \ddagger}$ \\
\hline $\mathrm{H}^{+}$flux, $\mathrm{mM} / \mathrm{min}$ & $7.99 \pm 0.740$ & $16.53 \pm 1.006^{* \S}$ & $7.82 \pm 0.768$ & $12.63 \pm 1.051^{* \ddagger}$ \\
\hline \multicolumn{5}{|l|}{$\mathrm{Cl}^{-}$readmission } \\
\hline $\mathrm{pH}, \max \mathrm{U} / \mathrm{min}$ & $0.175 \pm 0.014$ & $0.345 \pm 0.021 * \S$ & $0.178 \pm 0.013$ & $0.249 \pm 0.017 * \ddagger$ \\
\hline $\mathrm{H}^{+}$flux, $\mathrm{mM} / \mathrm{min}$ & $11.29 \pm 1.001$ & $22.53 \pm 1.709^{* \S}$ & $10.62 \pm 0.916$ & $14.96 \pm 1.131 * \ddagger$ \\
\hline
\end{tabular}

Two sequential $\mathrm{Cl}^{-}$removal/readmission maneuvers were performed, the second during exposure to secretin $(50 \mathrm{nM})$ or acetylcholine $(10 \mu \mathrm{M})$ plus secretin in IBDU pretreated and perfused with BAPTA/AM, an intracellular $\mathrm{Ca}^{2+}$ chelator. Data were compared with similar paired experiments performed in the absence of BAPTA/AM. ${ }^{*} P<0.02$ versus control values. ${ }^{\ddagger} P<0.03$ versus ACh plus secretin. ${ }^{\S} P<0.05$ versus secretin alone. Data are mean \pm SEM.

ization after $\mathrm{Cl}^{-}$removal and the maximal rate of $\mathrm{pH}_{\mathrm{i}}$ recovery after $\mathrm{Cl}^{-}$readmission measured during exposure to secretin were similar both in the absence and presence of FK-506. From the parameters measured after $\mathrm{Cl}^{-}$removal, the $\mathrm{Cl}^{-}$/ $\mathrm{HCO}_{3}{ }^{-}$exchanger activity appears to be similarly stimulated by secretin both in the absence $(+63 \%)$ and presence $(+70 \%)$ of FK-506, indicating that the calcineurin inhibitor has no impact on the stimulatory effect of secretin on the anion exchanger.

In contrast, in IBDU treated with FK-506, ACh failed to increase the response rate to secretin. In fact, the activity of the $\mathrm{Cl}^{-} / \mathrm{HCO}_{3}{ }^{-}$exchanger measured during exposure to secretin plus ACh (second manuever) was significantly lower $(P<$ 0.03 ) in IBDU treated with FK-506 in comparison to untreated controls (Fig. 5, Table V). In IBDU incubated with FK-506, the activity of the $\mathrm{Cl}^{-} / \mathrm{HCO}_{3}{ }^{-}$exchanger measured during exposure to secretin plus ACh (second maneuver) was significantly $(P<0.02)$ higher in comparison with the basal values (first control maneuver) but similar to that measured in the presence of secretin alone (Fig. 5, Table V). ACh plus secretin stimulated by $104 \%$ the $\mathrm{Cl}^{-} / \mathrm{HCO}_{3}{ }^{-}$exchanger activity in control IBDU, but only 53\% in FK-506 treated IBDU.

Table IV. Effect of Staurosporine on ACh plus Secretin Stimulation of the $\mathrm{Cl} / \mathrm{HCO}_{3}{ }^{-}$Exchanger Activity in IBDU

\begin{tabular}{|c|c|c|c|c|c|c|}
\hline & Stauro. & Stauro. & Control & $\begin{array}{l}\text { ACh plus } \\
\text { secretin }\end{array}$ & Stauro. & $\begin{array}{c}\text { Stauro. }+ \\
\text { ACh }+ \text { secretin }\end{array}$ \\
\hline & \multicolumn{2}{|c|}{$n=8$} & \multicolumn{2}{|c|}{$n=18$} & \multicolumn{2}{|c|}{$n=18$} \\
\hline $\begin{array}{l}\text { Basal } \mathrm{pH}_{\mathrm{i}} \\
\mathrm{Cl}^{-} \text {removal }\end{array}$ & $7.21 \pm 0.017$ & $7.19 \pm 0.015$ & $7.18 \pm 0.011$ & $7.20 \pm 0.012$ & $7.22 \pm 0.013$ & $7.21 \pm 0.013$ \\
\hline Delta $\mathrm{pH}_{\mathrm{i}}$ & $0.23 \pm 0.019$ & $0.25 \pm 0.019$ & $0.25 \pm 0.016$ & $0.32 \pm 0.017$ & $0.24 \pm 0.015$ & $0.31 \pm 0.017$ \\
\hline $\mathrm{pH}, \max \mathrm{U} / \min$ & $0.133 \pm 0.018$ & $0.148 \pm 0.020$ & $0.135 \pm 0.013$ & $0.298 \pm 0.019 *$ & $0.126 \pm 0.010$ & $0.281 \pm 0.017^{*}$ \\
\hline $\mathrm{H}^{+}$flux, $\mathrm{mM} / \mathrm{min}$ & $7.94 \pm 1.140$ & $8.83 \pm 1.002$ & $8.05 \pm 1.268$ & $17.78 \pm 1.081 *$ & $7.52 \pm 0.914$ & $16.78 \pm 1.302 *$ \\
\hline $\mathrm{Cl}^{-}$readmission & & & & & & \\
\hline $\mathrm{pH}, \max \mathrm{U} / \min$ & $0.191 \pm 0.019$ & $0.183 \pm 0.021$ & $0.169 \pm 0.012$ & $0.334 \pm 0.021 *$ & $0.163 \pm 0.011$ & $0.312 \pm 0.019^{*}$ \\
\hline $\mathrm{H}^{+}$flux, $\mathrm{mM} / \mathrm{min}$ & $11.80 \pm 1.511$ & $11.31 \pm 1.409$ & $10.42 \pm 1.214$ & $21.06 \pm 1.331 *$ & $10.11 \pm 1.223$ & $19.66 \pm 1.302 *$ \\
\hline
\end{tabular}

Two sequential $\mathrm{Cl}^{-}$removal/readmission maneuvers were performed, the second during exposure to ACh $(10 \mu \mathrm{M})$ plus 50 -nM secretin in IBDU perfused with $0.1-\mu \mathrm{M}$ staurosporine. Findings were compared with similar paired experiments performed in the absence of staurosporine. Control experiments with staurosporine alone were also performed. $* P<0.02$ versus control values. Data are mean \pm SEM. 

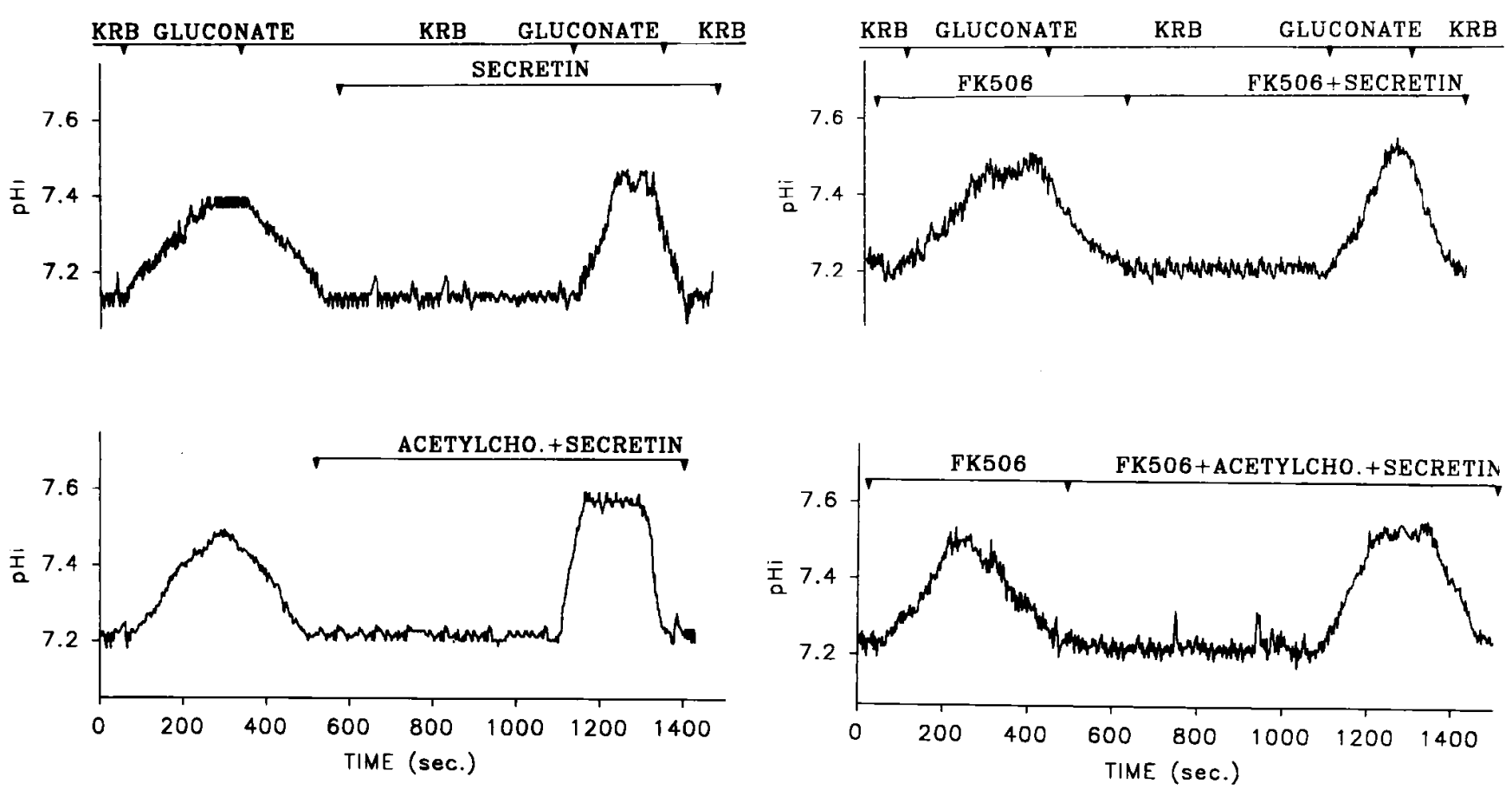

Figure 5. Effect of the calcineurin inhibitor, FK-506, on ACh plus secretin-induced stimulation of $\mathrm{Cl}^{-} / \mathrm{HCO}_{3}{ }^{-}$exchanger activity. IBDU, preincubated (30-45 min) with 100-nM FK-506, were submitted to two sequential $\mathrm{Cl}^{-}$removal/readmission maneuvers, the second during administration of secretin (top right) or secretin plus ACh (bottom right). The findings were compared with similar paired experiments performed in the absence of FK-506 (SECRETIN, top left; secretin plus ACh, bottom left). The maximal rate of alkalinization after $\mathrm{Cl}^{-}$removal and the maximal rate of $\mathrm{pH}_{\mathrm{i}}$ recovery after $\mathrm{Cl}^{-}$readmission measured during exposure to secretin were similar both in the absence and presence of FK-506. In contrast, in IBDU treated with FK-506, ACh failed to increase the response rate to secretin.

Cyclosporin A, a different calcineurin inhibitor, showed the same effects as those reported for FK-506. In fact, in IBDU preincubated (30-45 min) with 100-nM cyclosporin A, ACh plus secretin $(n=12)$ failed to significantly increase the $\mathrm{Cl}^{-} /$ $\mathrm{HCO}_{3}{ }^{-}$exchanger activity in comparison to that measured in the presence of secretin alone $(n=12)\left(\mathrm{Cl}^{-}\right.$removal $=$ $0.225 \pm 0.018$ versus $0.213 \pm 0.017 \mathrm{pHU} / \mathrm{min} ; \mathrm{H}^{+}$flux $=13.49 \pm$ 1.055 versus $12.69 \pm 1.033 \mathrm{mM} / \mathrm{min} ; \mathrm{Cl}^{-}$readmission $=0.265 \pm$ 0.018 versus $0.270 \pm 0.020 \mathrm{pHU} / \mathrm{min} ; \mathrm{H}^{+}$flux $=17.032 \pm 1.122$ versus $17.566 \pm 1.376 \mathrm{mM} / \mathrm{min})$. In these latter experiments (i.e., cyclosporin A plus secretin), the $\mathrm{Cl}^{-} / \mathrm{HCO}_{3}{ }^{-}$exchanger activity was similar to that measured during secretin exposure in control untreated IBDU $(n=12)\left(\mathrm{Cl}^{-}\right.$removal $=$ $0.208 \pm 0.014 \mathrm{pHU} / \mathrm{min} ; \mathrm{H}^{+}$flux $=12.23 \pm 1.126 \mathrm{mM} / \mathrm{min} ; \mathrm{Cl}^{-}$ readmission $=0.261 \pm 0.021 \mathrm{pHU} / \mathrm{min} ; \mathrm{H}^{+}$flux $=16.026 \pm$ $1.296 \mathrm{mM} / \mathrm{min})$ but significantly higher $(P<0.03)$ than the basal $\mathrm{Cl}^{-} / \mathrm{HCO}_{3}{ }^{-}$exchanger activity $\left(\mathrm{Cl}^{-}\right.$removal $=0.128 \pm$ $0.012 \mathrm{pHU} / \mathrm{min} ; \mathrm{H}^{+}$flux $=7.53 \pm 0.627 \mathrm{mM} / \mathrm{min} ; \mathrm{Cl}^{-}$readmission $=0.170 \pm 0.014 \mathrm{pHU} / \mathrm{min} ; \mathrm{H}^{+}$flux $=10.93 \pm 0.976 \mathrm{mM} /$ $\mathrm{min})$. These findings indicate that cyclosporin A blocks the effect of ACh but not that of secretin on the $\mathrm{Cl}^{-} / \mathrm{HCO}_{3}{ }^{-}$exchanger activity in IBDU.

Studies in isolated cholangiocytes. Virtually pure preparations of cholangiocytes were isolated from normal rat liver, a purity commonly achieved by immunoaffinity separation (27$31)$. Hepatocytes and mesenchymal cells were not present. Viability, assessed by trypan blue exclusion, was always $>99 \%$.

Molecular analysis by RT-PCR shows that cholangiocytes from normal rat liver express the transcript for CK-19, a specific marker of cholangiocytes $(3,34)$. As shown in Fig. 6 , the transcript for the M3 ACh receptor (375 bp) was present in brain (positive controls) but not in yeast transfer RNA (negative control). By RT-PCR, a 375-bp, 100\% homologous to the published sequence for the M3 ACh receptor (35), was detected in normal cholangiocytes.

On the contrary, we did not detect by RT-PCR the presence of the transcript for the M1 muscarinic ACh receptor in pure preparations of cholangiocytes from normal rat liver (three cell preparations).

cAMP intracellular levels in isolated cholangiocytes. Fig. 7 shows intracellular cAMP levels in isolated cholangiocytes incubated with agonists and inhibitors under experimental conditions similar to those used for the $\mathrm{pH}_{\mathrm{i}}$ measurement in IBDU. Secretin alone induced a twofold increase in cAMP basal levels $\left(38.0 \pm 1.08\right.$ versus $18.13 \pm 1.369 \mathrm{fmol} / 10^{5}$ cells; $P<$ $0.01)$, while $\mathrm{ACh}$ alone $\left(17.22 \pm 0.653 \mathrm{fmol} / 10^{5}\right.$ cells) showed no effect. However, when isolated cholangiocytes were exposed to secretin plus $\mathrm{ACh}$, the cAMP intracellular levels $\left(54.17 \pm 2.017 \mathrm{fmol} / 10^{5}\right.$ cells $)$, were significantly higher $(P<$ 0.01 ) than those measured in the presence of secretin alone. Similar findings were obtained with the muscarinic agonist, carbachol $(100 \mu \mathrm{M})$, which failed to significantly influence the basal values of cAMP $(20.93 \pm 0.408$ versus $17.654 \pm 2.338 \mathrm{fmol} /$ $10^{5}$ cells), but significantly increased the cAMP levels induced by secretin alone (carbachol plus secretin $=66.95 \pm 2.88$ versus secretin alone $=38.77 \pm 1.908 \mathrm{fmol} / 10^{5}$ cells; $P<0.01$ ).

Basal cAMP levels, in isolated cholangiocytes preincubated (45 min) with 100 -nM FK-506 (20.54 $\pm 0.872 \mathrm{fmol} / 10^{5}$ cells) or $100-\mathrm{nM}$ cyclosporin A $\left(19.36 \pm 0.41 \mathrm{fmol} / 10^{5}\right.$ cells $)$, were similar to the values in untreated cells (Fig. 7). In addition, se- 
Table V. Effect of the Calcineurin Inhibitor, FK-506, on Secretin and Secretin plus ACh Stimulation of the $\mathrm{Cl}^{-} / \mathrm{HCO}_{3}^{-}$Exchanger Activity in IBDU

\begin{tabular}{|c|c|c|c|c|}
\hline & Control & Secretin & FK-506 & $\begin{array}{l}\text { FK-506 plus } \\
\text { secretin }\end{array}$ \\
\hline & \multicolumn{2}{|c|}{$n=13$} & \multicolumn{2}{|c|}{$n=13$} \\
\hline Basal $\mathrm{pH}_{\mathrm{i}}$ & $7.20 \pm 0.013$ & $7.21 \pm 0.013$ & $7.18 \pm 0.014$ & $7.17 \pm 0.014$ \\
\hline \multicolumn{5}{|l|}{$\mathrm{Cl}^{-}$removal } \\
\hline Delta $\mathrm{pH}_{\mathrm{i}}$ & $0.23 \pm 0.016$ & $0.28 \pm 0.017$ & $0.22 \pm 0.015$ & $0.26 \pm 0.017$ \\
\hline $\mathrm{pH}, \max \mathrm{U} / \mathrm{min}$ & $0.125 \pm 0.013$ & $0.204 \pm 0.017 *$ & $0.130 \pm 0.014$ & $0.221 \pm 0.020^{*}$ \\
\hline $\mathrm{H}^{+}$flux, $\mathrm{mM} / \mathrm{min}$ & $7.41 \pm 0.693$ & $12.03 \pm 1.102 *$ & $8.02 \pm 0.995$ & $13.13 \pm 1.133^{*}$ \\
\hline \multicolumn{5}{|l|}{$\mathrm{Cl}^{-}$readmission } \\
\hline $\mathrm{pH}, \max \mathrm{U} / \min$ & $0.167 \pm 0.015$ & $0.277 \pm 0.019 *$ & $0.175 \pm 0.017$ & $0.269 \pm 0.019 *$ \\
\hline \multirow[t]{3}{*}{$\mathrm{H}^{+}$flux, $\mathrm{mM} / \min$} & $10.81 \pm 1.067$ & $16.731 \pm 1.408^{*}$ & $11.053 \pm 1.116$ & $17.16 \pm 1.243^{*}$ \\
\hline & Control & $\begin{array}{l}\text { ACh plus } \\
\text { secretin }\end{array}$ & FK-506 & $\begin{array}{c}\text { FK-506 + } \\
\text { secretin+ ACh }\end{array}$ \\
\hline & \multicolumn{2}{|c|}{$n=18$} & \multicolumn{2}{|c|}{$n=18$} \\
\hline Basal $\mathrm{pH}_{\mathrm{i}}$ & $7.21 \pm 0.012$ & $7.19 \pm 0.013$ & $7.23 \pm 0.012$ & $7.22 \pm 0.013$ \\
\hline \multicolumn{5}{|l|}{$\mathrm{Cl}^{-}$removal } \\
\hline Delta $\mathrm{pH}_{\mathrm{i}}$ & $0.24 \pm 0.013$ & $0.32 \pm 0.016$ & $0.26 \pm 0.012$ & $0.29 \pm 0.013$ \\
\hline $\mathrm{pH}, \max \mathrm{U} / \min$ & $0.135 \pm 0.010$ & $0.275 \pm 0.016^{* \S}$ & $0.142 \pm 0.014$ & $0.217 \pm 0.017 *$ \\
\hline $\mathrm{H}^{+}$flux, $\mathrm{mM} / \mathrm{min}$ & $8.11 \pm 0.723$ & $16.93 \pm 1.143 * \S$ & $8.05 \pm 0.786$ & $11.99 \pm 1.081^{* \ddagger}$ \\
\hline \multicolumn{5}{|l|}{$\mathrm{Cl}^{-}$readmission } \\
\hline $\mathrm{pH}, \max \mathrm{U} / \min$ & $0.187 \pm 0.015$ & $0.351 \pm 0.022 * \S$ & $0.181 \pm 0.014$ & $0.260 \pm 0.017^{* \ddagger}$ \\
\hline $\mathrm{H}^{+}$flux, $\mathrm{mM} / \min$ & $11.463 \pm 1.206$ & $22.766 \pm 1.699 * 8$ & $10.902 \pm 1.021$ & $15.636 \pm 1.111^{* \frac{1}{+}}$ \\
\hline
\end{tabular}

Two sequential $\mathrm{Cl}^{-}$removal/readmission maneuvers were performed, the second during exposure to secretin $(50 \mathrm{nM})$ or $\mathrm{ACh}(10 \mu \mathrm{M})$ plus secretin in IBDU pretreated and perfused with FK-506, a calcineurin inhibitor. Data were compared with similar paired experiments performed in the absence of FK-506. ${ }^{*} P<0.02$ versus control values. ${ }^{\ddagger} P<0.03$ versus ACh plus secretin. ${ }^{\circledR} P<0.05$ versus secretin alone. Data are mean \pm SEM.

cretin induced a cAMP increase similar to untreated cells $\left(35.03 \pm 2.70 \mathrm{fmol} / 10^{5}\right.$ cells with FK-506 plus secretin and $32.25 \pm 0.358 \mathrm{fmol} / 10^{5}$ cells with cyclosporin A plus secretin; $P<0.01$ versus FK-506 or cyclosporin A alone) (Fig. 7). In contrast, in isolated cholangiocytes preincubated with FK-506 or cyclosporin A, ACh plus secretin induced no further increase in cAMP levels $\left(32.60 \pm 1.08\right.$ and $34.66 \pm 1.91 \mathrm{fmol} / 10^{5}$ cells, respectively) in comparison with secretin alone. These experiments indicate that ACh potentiation of secretin-stimulated cAMP accumulation is dependent on calcineurin activity in that it is blocked by two distinct inhibitors of calcineurin.

\section{Discussion}

The main findings emerging from this study are that: (a) M3 ACh receptors are present in IBDU of different sizes, while M1 and M2 subtypes are absent; $(b)$ ACh has no effect on the basal activity of the $\mathrm{Cl}^{-} / \mathrm{HCO}_{3}^{-}$exchanger, but it significantly potentiates the stimulatory effect of secretin on this anion exchanger; (c) the effect of ACh is abolished by 4-DAMP, a muscarinic receptor antagonist with high affinity for M3 subtype; (d) the ACh-induced potentiation of the secretin stimulatory effect on the $\mathrm{Cl}^{-} / \mathrm{HCO}_{3}{ }^{-}$exchanger appears to be mediated by intracellular $\mathrm{Ca}^{2+}$ as it is sensitive to the intracellular $\mathrm{Ca}^{2+}$ chelator BAPTA/AM, but is not mediated by PKC as it is staurosporine insensitive; and $(e)$ ACh acts by potentiating the secretin induced cAMP intracellular levels, through a calcineurin mediated regulation of adenylyl cyclase activity.

ACh muscarinic receptors are presently classified into four major subtypes (M1-M4) with different tissue distribution, pharmacology, and functions (42-46). At least five distinct but related muscarinic genes (m1-m5) have been demonstrated recently by molecular cloning studies, but the expressed product of the $\mathrm{m} 5$ receptor gene does not yet have an equivalent functional pharmacological profile nor a defined tissue localization (42-46). From a functional point of view, M1, M3, and M5 are preferentially coupled to hydrolysis of phosphoinositide, while M2 and M4 to the inhibition of the adenylyl cyclase activity (42-46). In this study we used a monoclonal antibody to detect the occurrence of muscarin receptors in IBDU by immunofluorescence and immunoelectron microscopy. The antibody used (M35) recognizes both M2 and M3 subtype receptors (21-23), but the immunofluorescence study performed by using another antibody specific for M2 subtypes yielded negative findings, suggesting that those findings obtained with M35 are related to the distribution of M3 receptor subtypes. These appeared extensively represented in cholangiocytes without differences relative to the size of the ducts, but with a significantly higher staining of the basolateral compared to the apical membranes. In addition, at the ultrastructural level there was a preferential localization at the level of invaginations of the cell membrane with subcellular features reminiscent of coated pits, suggesting a process of receptor-mediated endocytosis. The occurrence of $\mathrm{M} 3$ receptor subtypes has also been confirmed by the RT-PCR analysis performed in pure preparations of rat cholangiocytes. On the contrary, M2 subtype receptors were not found by indirect immunofluorescence in IBDU and, the transcript for M1 subtype receptor, was not detected by RT- 

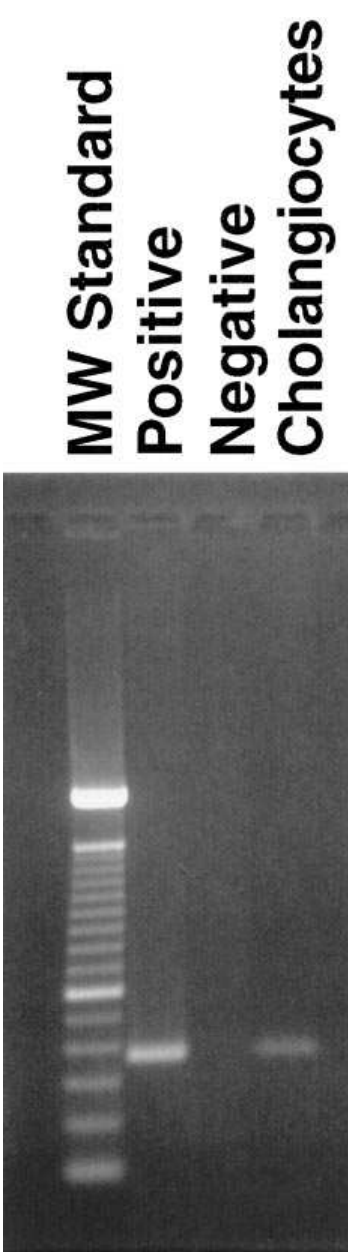

\section{M3 Acetylcholine receptor mRNA $375 \mathrm{bp}$}

Figure 6. RT-PCR analysis of M3 ACh receptor. By RT-PCR, a 375bp, $100 \%$ homologous to the published sequence for $\mathrm{m} 3 \mathrm{ACh}$ receptor (35), was detected in normal cholangiocytes. The transcript for M3 acetylcholine receptor (375 bp) was present in brain (Positive) but not in yeast transfer RNA (Negative).

PCR, in virtually pure $(27,30,31,39)$ preparations of cholangiocytes. This latter finding is in contrast with recent observations (37) showing the presence of M1 subtype ACh receptor mRNA in impure $(75 \%$ by $\gamma$-GT staining) preparations of rat cholangiocytes. The discrepancies between the molecular results, performed with the same RT-PCR methodology, presumably depend on the degree of purity of cholangiocyte preparation.

In peripheral tissues, M3 receptor subtypes have been detected in smooth muscles, exocrine glands, urinary bladder, small intestine and gastric antral cells (42-45). Stimulation of muscarinic receptors, either by ACh from parasympathetic nerves or muscarinic agonists, induced secretion in exocrine glands including tear glands, sweat glands, salivary glands, and pancreas $(16,17,42,44)$. In all these tissues, Northern blot analysis and receptor specific antibody immunoprecipitation studies indicate the presence of M1 and M3 receptors which are frequently coexpressed and are both coupled to hydrolysis of phosphoinositide and $\mathrm{Ca}^{2+}$ increase (42-44).

Functional studies. Bicarbonate secretion in the lumen of intrahepatic ducts is one of the major functions of cholangio- cytes (1-4). This is driven by the $\mathrm{Cl}^{-} / \mathrm{HCO}_{3}{ }^{-}$exchanger, an anion exchanger that has been identified by immunohistochemistry in the apical pole of human cholangiocytes (47), and functionally characterized in the rat (4) and human isolated cholangiocytes (48). The $\mathrm{Cl}^{-} / \mathrm{HCO}_{3}{ }^{-}$exchanger, thought to be the major mechanism of bicarbonate excretion in a number of bicarbonate secretory epithelia, is stimulated by different hormones targeting cholangiocytes, including secretin $(4,19,29$, 33 ), bombesin (5), and vasoactive intestinal peptide (6), thus providing the basis for hormonal induced bicarbonate rich ductal choleresis. In IBDU, forskolin, secretin, bombesin, and vasoactive intestinal peptide, by enhancing the activity of the anion exchanger, induce an expansion of lumenal space together with an alkalinization of lumenal $\mathrm{pH}$, as direct evidence of stimulated bicarbonate-rich ductal fluid secretion (4-6, 19). We explored the effect of ACh on both basal and secretin stimulated $\mathrm{Cl}^{-} / \mathrm{HCO}_{3}{ }^{-}$exchanger activity by using a method $\left(\mathrm{pH}_{\mathrm{i}}\right.$ changes induced by acute $\mathrm{Cl}^{-}$removal/readmission) widely used to assess the activity of this anion exchanger (2,

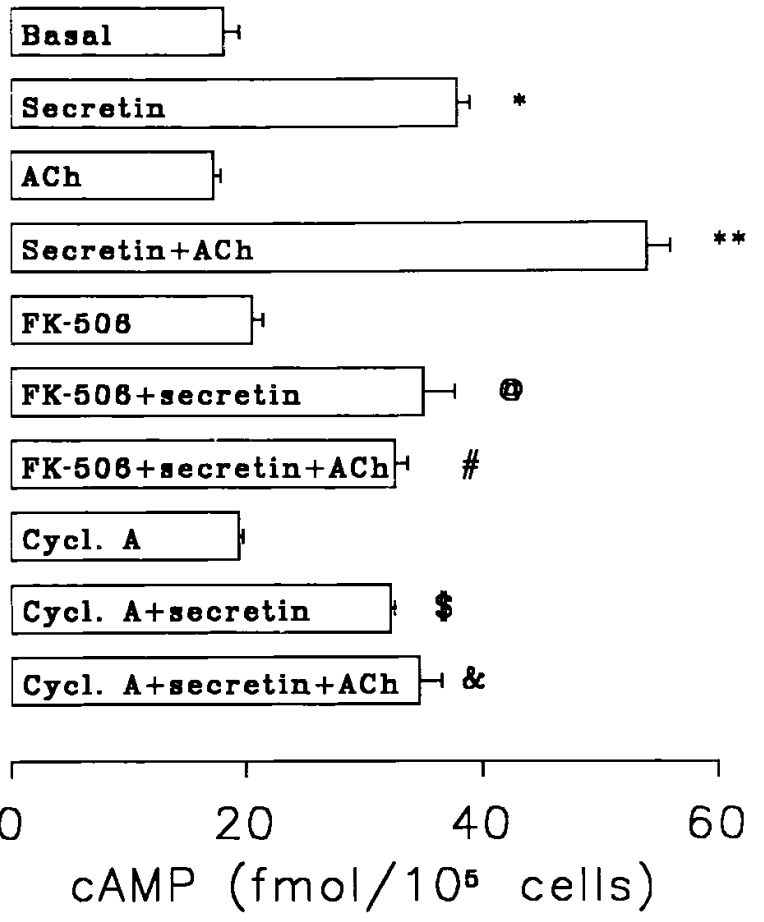

Figure 7. cAMP intracellular levels in isolated cholangiocytes incubated with agonists and inhibitors under the same experimental conditions as those for the $\mathrm{pH}_{\mathrm{i}}$ measurement in IBDU. Secretin alone $(50 \mathrm{nM})$ induced a twofold increase $(P<0.01)$ in cAMP basal levels, while ACh $(10 \mu \mathrm{M})$ alone showed no effect. However, when isolated cholangiocytes were exposed to secretin plus ACh, the cAMP intracellular levels were significantly higher $(P<0.01)$ than those measured in the presence of secretin alone. Preincubation $(45 \mathrm{~min})$ with 100-nM FK-506 or 100-nM cyclosporin A does not affect basal- nor secretin-induced cAMP levels. However, in isolated cholangiocytes preincubated with FK-506 or cyclosporin A, ACh plus secretin induced no further increase in cAMP levels in comparison with secretin alone. Data are mean \pm SEM from 3-15 experiments. Statistical comparison was performed using the ANOVA. $* P<0.01$ versus basal; ** $P<0.01$ versus secretin or basal; @ $P<0.01$ versus FK-506; \#, $P<$ 0.01 versus FK-506; $\$, P<0.01$ versus cyclosporin A; $\&, P<0.01$ versus cyclosporin A. 
$4-6,19,25,26,29)$. The rationale for studying the coordinated effect of secretin and ACh derives from the fact that secretin targets the intrahepatic biliary epithelium in a period (digestive phase) of parasympathetic predominance $(9,10)$. We have found that $\mathrm{ACh}$ alone induced no significant stimulation of the $\mathrm{Cl}^{-} / \mathrm{HCO}_{3}^{-}$exchanger activity. This is in agreement with a previous study (18) showing that $\mathrm{ACh}$ alone failed to stimulate fluid secretion in the lumenal space of rat IBDU in spite of a significant increase of cytosolic $\mathrm{Ca}^{2+}$ signaling. However, when administered alone, ACh failed to stimulate fluid secretion (18) and the activity of the anion exchanger, but potentiated the secretin stimulation of the $\mathrm{Cl}^{-} / \mathrm{HCO}_{3}{ }^{-}$exchanger activity by $\sim 50 \%$. The ACh-induced potentiation of the secretin effect on $\mathrm{Cl}^{-} / \mathrm{HCO}_{3}{ }^{-}$exchanger activity was blocked by 4-DAMP, a muscarinic receptor antagonist which possesses 10-20-fold functional selectivity toward M3 over M2 receptors, but which cannot functionally discriminate between M1 and M3 muscarinic receptors $(21-23,42)$. Having excluded by RT-PCR the occurrence of M1 receptor subtypes, the sensitivity to 4-DAMP indicates that the effects of ACh are mediated by the activation of M3 subtype muscarinic receptors. An aspecific effect of 4-DAMP may be excluded since the stimulation of $\mathrm{Cl}^{-} / \mathrm{HCO}_{3}{ }^{-}$ exchanger activity induced by secretin alone was not influenced.

ACh signal transduction pathway. ACh is known to elicit $\mathrm{Ca}^{2+}$ signaling in IBDU involving both influx of extracellular $\mathrm{Ca}^{2+}$ and mobilization of thapsigargin-sensitive $\mathrm{Ca}^{2+}$ stores (18). We have shown that the intracellular $\mathrm{Ca}^{2+}$ chelating agent, BAPTA/AM, blocks the effect of ACh on secretin stimulation of $\mathrm{Cl}^{-} / \mathrm{HCO}_{3}{ }^{-}$exchanger activity. Thus, $\mathrm{Ca}^{2+}$ should be considered the primary mediator of $\mathrm{ACh}$-induced potentiation of secretin effect on the $\mathrm{Cl}^{-} / \mathrm{HCO}_{3}{ }^{-}$exchanger activity. ACh does not appear to act via a $\mathrm{Ca}^{2+}$-activated $\mathrm{PKC}$, since the $\mathrm{PKC}$ antagonist staurosporine failed to block potentiation of secretin-stimulated $\mathrm{Cl}^{-} / \mathrm{HCO}_{3}{ }^{-}$exchanger activity induced by ACh. For both BAPTA/AM and staurosporine, an aspecific toxic effect could be excluded by the fact that these substances did not influence the intracellular $\mathrm{pH}_{\mathrm{i}}$, the basal activity of the $\mathrm{Cl}^{-} / \mathrm{HCO}_{3}{ }^{-}$exchanger, nor the rate of response to secretin alone. To further elucidate the ACh mechanism of action, we measured cAMP intracellular levels in isolated cholangiocytes. While ACh alone failed to influence the intracellular levels of cAMP, when administered together with secretin, ACh doubled the secretin-induced cAMP intracellular accumulation indicating a sensitization of adenylyl cyclase to secretin. An effect of ACh on cAMP breakdown may be excluded since measurement of cAMP intracellular levels have been performed in the presence of IBMX concentration that should fully inhibit soluble phosphodiesterases. An increase in adenylyl cyclase activity has been reported in different cell types after stimulation of M1, M3, and M5 receptor subtypes and this effect is thought to occur by activation, via IP3/Ca ${ }^{2+}$, of $\mathrm{Ca}^{2+}$-sensitive adenylyl cyclase isoforms (42,49-53). On the contrary, stimulation of M2/M4 subtype receptors generally has been coupled with an inhibition of a previously stimulated adenylyl cyclase, via pertussis toxin-sensitive $\mathrm{G}$ proteins (4246, 49). However, M2 receptor subtypes have been not detected by immunofluorescence in IBDU and M4 subtypes have only been detected so far in the rat striatum and rabbit lung, but not in the pancreas, intestine, or salivary glands (4246, 49).

Thus our findings indicate that ACh elicits a sensitization of the adenylyl cyclase complex to cAMP agonists, such as se- cretin, by a mechanism of interaction at the second messenger level. This mechanism is responsible of the ACh-induced potentiation of the secretin stimulatory effect on the $\mathrm{Cl}^{-} / \mathrm{HCO}_{3}{ }^{-}$ exchanger. In secretory epithelia, including colonic cell lines (53), intestinal epithelia (54), pancreatic acini $(51,55)$, salivary glands (16) and gastric chief cells (56), cross-talk between the $\mathrm{Ca}^{2+}$ and cAMP signaling pathways has been shown to be of relevance in the regulation of secretory processes. It is known that $\mathrm{Ca}^{2+}$ may regulate cAMP production, but the mechanisms of the cross-talk between the two signaling pathways have only recently begun to be investigated at a molecular level. PKC, G proteins, $\mathrm{Ca}^{2+}$-calmodulin complex, and calcineurin have been differently involved as regulatory components of the cascade (53-58). The cross-talk between $\mathrm{Ca}^{2+}$ and cAMP signaling pathways may be responsible for either potentiating or terminating agonist-stimulated second messenger level, depending on the cell system under investigation. In our cell system, the cross-talk between signaling pathways seems to be mediated by calcineurin, since two distinct calcineurin inhibitors (cyclosporin A and FK-506), without influencing other cell function parameters, blocked the stimulatory effect of ACh on secretin-induced cAMP levels and $\mathrm{Cl}^{-} / \mathrm{HCO}_{3}{ }^{-}$exchanger activity. Moreover, the rabbit anti-protein phosphatase $2 \mathrm{~B} \alpha$ polyclonal antibody (i.e., calcineurin) yielded a specific reaction product on normal IBDU, as shown by indirect immunofluorescence (personal observation). The inhibitory effect of FK-506 and cyclosporin A on calcineurin activity has been widely documented in many different cell types where it depends on binding to the immunophillins FK-binding protein 12 (FK506) and cyclophillin (cyclosporine) $(40,41)$. Calcineurin is a $\mathrm{Ca}^{2+}$-calmodulin-dependent serine/threonine phosphatase $2 \mathrm{~B}$, which plays a role in signal transduction in different secretory epithelia other than in nervous tissues $(40,41)$. Calcineurin activation, in fact, induces enzyme secretion in pancreatic acini, zymogen granule fusion in parotid glands, and pepsinogen secretion in gastric chief cells $(55,56,59)$. In a number of different cell types $(52,55,56,59), \mathrm{Ca}^{2+}$ agonists have been shown to regulate adenylyl cyclase activity by a $\mathrm{Ca}^{2+}$-calmodulin-dependent activation of calcineurin that in turn selectively acts on certain adenylyl cyclase isoforms. At least ten different isoforms of adenylyl cyclases have been described to date (60-65). Other than having distinct tissue distribution profiles, they largely differ with respect to regulation by $\mathrm{G}$ proteins, $\mathrm{Ca}^{2+}$ calmodulin, calcineurin and PKC (60-65). Isoforms I, III, and VIII have been reported to be stimulated by the $\mathrm{Ca}^{2+}$-calmodulin complex and/or calcineurin (63-65). In dispersed gastric chief cells, $\mathrm{Ca}^{2+}$ mobilizing agents, including cholinergic agonists, lead to a potentiation of cholera toxinand forskolin-induced pepsinogen secretion by an augmentation of cAMP cellular levels and, recently, calcineurin has been proposed as the mediator of the cross-talk between the $\mathrm{Ca}^{2+}$ and adenylyl cyclase signaling pathways (56). In bovine adrenal glomerulosa cells (52), angiotensin II induced enhancement of ACTH-stimulated cAMP formation, an effect partially mediated by PKC (staurosporine sensitivity) and completely by calcineurin (inhibition by FK-506 and cyclosporine). In this study, a regulation of $\mathrm{G}$ proteins and/or adenylyl cyclase activities by phosphorylation/dephosphorylation steps (PKC/calcineurin) has been suggested as the underlying mechanism of the crosstalk between $\mathrm{Ca}^{2+}$ and cAMP. On the contrary, in other cell systems, including mouse pituitary tumor (AT10) cells (57), calcineurin exerts a feedback inhibition of agonist-evoked cAMP 
formation, an effect also documented in purified bovine brain adenynyl cyclase (66). Expression of different isoforms of adenylyl cyclase or $\mathrm{G}$ proteins could explain the divergent effects of $\mathrm{Ca}^{2+}$ documented in different cell types.

Since ATP, like ACh, elicits cytosolic $\mathrm{Ca}^{2+}$ signaling in IBDU without a direct effect on fluid secretion (18), the interaction of ATP with secretin or other cAMP agonists in modulating ductal fluid secretion should be investigated in light of the present findings.

In conclusion, this study provides morphological and functional evidence that $\mathrm{ACh}$ plays a role in the regulation of bicarbonate secretion from biliary ducts. This regulation probably takes place during the digestive phase when the parasympathetic system predominates and secretin targets the biliary epithelium. In this phase the bicarbonate requirement in the intestine is maximal. By acting on M3 receptor subtypes, ACh induces a $\mathrm{Ca}^{2+}$-calcineurin mediated potentiation of the secretin-induced adenylyl cyclase activity. The doubled cAMP intracellular levels generate an almost maximal stimulation of $\mathrm{Cl}^{-} / \mathrm{HCO}_{3}{ }^{-}$exchanges and bicarbonate excretion in the ductal lumen. The modulating action of $\mathrm{Ca}^{2+}$ on adenylyl cyclase could serve as a means of amplifying the secretory response and prevent the impairment of the overall secretory process.

\section{Acknowledgments}

This work was supported by Consiglio Nazionale olelle Ricerche (Progetto finalizzato FATMA, 94.00527PF41), by CNR (96.03444.CT04), by CNR (96.03445.CT04).

\section{References}

1. Roberts, S.K., and N.F. LaRusso. 1994. Pathobiology of biliary epithelia. Curr. Opin. Gastroenterol. 10:526-533.

2. Boyer, J.L. 1996. Bile duct epithelium: frontiers in transport physiology. Am. J. Physiol. 270:G1-G5.

3. Alpini, G., I.O. Phillips, and N.F. LaRusso. 1994. The biology of biliary epithelia. In The Liver: Biology and Pathobiology. I.M. Arias, N. Fausto, W.B. Jacoby, D.A. Schachter, and D.A. Shafritz, editors. Raven Press, Ltd., New York. 623-653.

4. Alvaro, D., W.K. Cho, A. Mennone, and J.L. Boyer. 1993. Effect of secretin on intracellular $\mathrm{pH}$ regulation in isolated rat bile duct epithelial cells. $J$. Clin. Invest. 92:1314-1325.

5. Cho, W.K., A. Mennone, and J.L. Boyer. 1995. Effect of bombesin on secretion in isolated polarized intrahepatic bile ductular units (IBDU). Gastroenterology. 108:A1049.

6. Cho, W.K., A. Mennone, S.A. Rydberg, and J.L. Boyer. 1995. VIP is a potent stimulus of bicarbonate and fluid secretion in bile ducts. Hepatology. 22: A294.

7. Tietz, P.S., G. Alpini, L.D. Pham, and N.F. LaRusso. 1995. Somatostatin inhibits secretin-induced ductal hypercholeresis and exocytosis by cholangiocytes. Am. J. Physiol. 269:G110-G118.

8. Glaser, S.S., R. Rodgers, J. Phinizy, W.E. Robertson, J. Lasater, G. LeSage, and G. Alpini. 1996. Gastrin inhibits secretin-induced hypercholeresis in the bile duct ligated rat liver through the cAMP system. Gastroenterology. 110:1197.

9. Walsh, J.H., and E.A. Mayer. 1993. Gastrointestinal hormones. In Gastrointestinal Disease, 5th Ed. M.H. Sleisenger and J.S. Fordtran, editors. W.B. Saunders Company Ltd., London. 18-44.

10. Walsh, J.H. Gastrointestinal hormones and peptides. 1981. In Physiology of the Gastrointestinal Tract. L.R. Johnson, editor. Raven Press, Ltd., New York. 59-144.

11. Tanturi, C.A., and A.C. Ivy. 1938. On the existence of secretory nerves in the vagi for and the reflex excitation and inhibition of bile secretion. Am. $J$. Physiol. 121:270-283.

12. Kaminski, D.L., J. Dorighi, and M. Jellinek. 1994. Effect of electrical vagal stimulation on canine hepatic bile flow. Effect of electrical vagal stimulation on canine hepatic bile flow. Am. J. Physiol. 227:487-493.

13. Pass, M., and T. Heath. 1976. Effect of electrical stimulation of the vagus nerves on bile secretion in anaesthetized sheep. Aust. J. Biol. Sci. 29:351-355.

14. Nahrwold, D.L., D.L. Kaminski, and R.C. Rose. 1972. Cholinergic con- trol of bile flow and composition. Physiologist. 15:224.

15. Frizzel, R.A., and A.P. Morris. 1994. Chloride conductance of saltsecreting epithelial cells. In Current Topics in Membranes. Academic Press, Inc., Orlando. 42:173-214.

16. Larsson, O., and L. Olgart, 1989. The enhancement of carbachol-induced salivary secretion by VIP and CGRP in rat parotid gland is mimicked by forskolin. Acta Physiol. Scand. 137:231-236.

17. Sato, K., and F. Sato. 1981. Role of calcium in cholinergic and adrenergic mechanisms of eccrine sweat secretion. Am. J. Physiol. 241:C113-C120.

18. Nathanson, M.H., A.D. Burgstahler, A. Mennone, and J.L. Boyer. 1996. Characterization of cytosolic $\mathrm{Ca}^{2+}$ signaling in rat bile duct epithelia. Am. $J$. Physiol. 271:G86-G96.

19. Mennone, A., D. Alvaro, W. Cho, and J.L. Boyer. 1995. Isolation of small polarized bile duct units. Proc. Natl. Acad. Sci. USA. 92:6527-6531.

20. Benedetti, A., L. Marucci, C. Bassotti, R. Mancini, S. Contucci, A.M. Jezequel, and F. Orlandi. 1993. Tubulo-vesicular transcytotic pathway in rat biliary epithelium: a study in perfused liver and in isolated intrahepatic bile duct. Hepatology. 18:422-432.

21. Andre, C., J.B. DeBacker, J.P. Guillet, J.C. Venderheyden, P. Vauquelin, and A.D. Strosberg. 1983. Purification of muscarinic acetylcholine receptors by affinity chromatography. EMBO (Eur. Mol. Biol. Organ.) J. 2:499-504.

22. Andre, C., J.P. Guillet, J.P. DeBacker, J.G. Venderheyden, J. Hoebeke, and A.D. Strosberg. 1984. Monoclonal antibodies against the native or denaturated forms of muscarinic acetylcholine receptor. EMBO (Eur. Mol. Biol. Organ.) J. 3:17-21

23. Andre, C., S. Marullo, J.G. Guillet, A. Convents, M. Lauwereys, S. Kaveri, J. Hoebeke, and A.D. Strosberg. 1987. Immunochemical studies of the muscarinic acetylcholine receptor. J. Recept. Res. 7:65-107.

24. Takahashi, T., J.M. Lasker, A.S. Rosman, and C.S. Lieber. 1993. Induction of cytochrome P-4502E1 in the human liver by ethanol is caused by a corresponding increase in encoding messenger RNA. Hepatology. 17:236-245.

25. Alvaro, D., P. Della Guardia, A. Bini, A. Gigliozzi, S. Furfaro, T. La Rosa, C. Piat, and L. Capocaccia. 1995. Effect of glucagon on intracellular pH regulation in isolated rat hepatocyte couplets. J. Clin. Invest. 96:665-675.

26. Alvaro, D., A. Mennone, and J.L. Boyer. 1993. Effect of ursodeoxycholic acid on intracellular $\mathrm{pH}$ regulation in isolated rat bile duct epithelial cells. Am. J. Physiol. 265:G783-G791.

27. Ishii, M., B. Vroman, and N.F. LaRusso. 1989. Isolation and morphologic characterization of bile duct epithelial cells from normal rat liver. Gastroenterology. 97:1236-1247.

28. Alpini, G., S. Roberts, J. Phinizy, W. Robertson, S. Gubba, O. Colegio, G. LeSage, and N.F. LaRusso. 1995. Heterogeneity of the proliferative capacity of rat cholangiocytes. Gastroenterology. 1098:A1025. (Abstr.)

29. LeSage, G., S.S. Glaser, S. Gubba, W.E. Robertson, J.L. Phinizy, J. Lasater, R.E. Rodgers, and G. Alpini. 1996. Regrowth of the rat biliary tree after $70 \%$ partial hepatectomy is coupled to increased secretin-induced ductal secretion. Gastroenterology. 111:1633-1644.

30. Alpini, G., G.D. Ulrich, J.O. Phillips, L.D. Pham, L.J. Miller, and N.F. LaRusso. 1994. Upregulation of secretin receptor gene expression in rat cholangiocytes after bile ligation. Am. J. Physiol. 266:G922-G928.

31. Alpini, G., S.K. Roberts, S.M. Kuntz, Y. Ueno, S. Gubba, P. Podila, G LeSage, and N.F. LaRusso. 1996. Morphological, molecular and functional heterogeneity of cholangiocytes from normal rat liver. Gastroenterology. 110:16361643 .

32. Rutemburg, A.M., H. Kim, J.W. Fischbein, J.S. Hanker, H.L. Wasserkrug, and A.M. Seligman. 1969. Histochemical and ultrastructural demonstration of gamma-glutamyl transpeptidase activity. J. Histochem. Cytochem. 17:517526.

33. Alpini, G., R. Lenzi, L. Sarkozi, and N. Tavoloni. 1988. Biliary physiology in rats with bile ductular cell hyperplasia. Evidence for a secretory function of proliferated bile ductules. J. Clin. Invest. 81:569-578.

34. Alpini, G., R. Lenzi, W.R. Zhai, M.H. Liu, P.A. Slott, F. Paronetto, and N. Tavoloni. 1989. Isolation of a nonparenchymal liver cell fraction enriched in cells with biliary epithelial phenotypes. Gastroenterology. 97:1248-1260.

35. Bonner, T., N. Buckely, A. Young, and M. Brann. 1987. Identification of a family of muscarinic acetylcholine genes. Science (Wash. DC). 237:527-532.

36. Peralta, E.G., J.W. Winslow, G.L. Peterson, D.H. Smith, A. Ashkenazi, J. Ramachandran, M.I. Schimerlik, and D.J. Capon. 1987. Primary structure and biochemical properties of an M2 muscarinic receptor. Science (Wash. DC). 236:600-606.

37. Elsing, C., C. Hübner, B.A. Fitscher, A. Kassner, and W. Stremmel. 1997. Muscarinic acetylcholine receptor stimulation of biliary epithelial cells and its effect on bile secretion in the isolated perfused rat liver. Hepatology. 25: 804-813.

38. Calnek, D., and A. Quaroni. 1993. Differential localization by in situ hybridization of distinct keratin mRNA species during intestinal epithelial cell development and differentiation. Differentiation. 53:95-104.

39. Kato, A., G.J. Gores, and N.F. LaRusso. 1992. Secretin stimulates exocytosis in isolated bile duct epithelial cells by a cyclic AMP-mediated mechanism. J. Biol. Chem. 267:15523-15529.

40. Morris, R. 1994. Model of action of FK506, cyclosporin A and rapamycin. Transplant. Proc. 26:3272-3275. 
41. Schreiber, S.L., and G.R. Crabtree. 1992. The mechanism of action of cyclosporin A and FK506. Immunol. Today. 13:136-142.

42. Caulfield, M.P. 1993. Muscarinic receptors-Characterization, coupling and function. Pharmacol. Ther. 58:319-379.

43. Dorje, F., A.I. Levey, and M.R. Brann. 1991. Immunological detection of muscarinic receptor subtype proteins $(\mathrm{m} 1-\mathrm{m} 5)$ in rabbit peripheral tissue. Mol. Pharmacol. 40:459-462.

44. Maeda, A., T. Kubo, M. Mishina, and S. Numa. 1988. Tissue distribution of mRNAs encoding muscarinic acetylcholine receptor subtypes. FEBS Lett. 239:339-342.

45. Weigert, N., K. Schaffer, U. Wegner, V. Schusdziarra, M. Classen, and W. Schepp. 1994. Functional characterization of a muscarinic receptor stimulating gastrin release from rabbit antral G-cells in primary culture. Eur. J. Pharmacol. 264:337-344.

46. Barlow, R.B., K.J. Berry, P.A.M. Glenton, N.M. Nikolaou, and K.S. Soh. 1976. A comparison of affinity constant for muscarinic-sensitive acetylcholine receptors in guinea-pig atrial pacemaker cells at $29^{\circ} \mathrm{C}$ and in ileum at $29^{\circ} \mathrm{C}$ and $37^{\circ} \mathrm{C}$. Br. J. Pharmacol. 58:613-620.

47. Martinez-Anso, E., J.E. Castillo, J. Diez, J.F. Medina, and J. Prieto. 1994. Immunohistochemical detection of chloride/bicarbonate anion exchanger in human liver. Hepatology. 19:1400-1406.

48. Strazzabosco, M., R. Joplin, A. Zeembery, A, Granato, C. Spirli, C. Poci, and S. Crepaldi 1994. Bicarbonate transport in cultured human intrahepatic bile duct epithelial cells (hBDE) from normal subjects and patients with primary biliary cirrhosis (PBC). Hepatology. 2:404A.

49. Jones, S.V.P., A.I. Levey, D.M. Weiner, J. Ellis, E. Novotny, S.H. Yu, F. Dorje, J. Wess, and M.R. Brann. 1992. Muscarinic acetylcholine receptors. In Molecular Biology of G-protein Coupled Receptors. M. Brann, editor. Birkhauser Boston, Cambridge, MA. 170-197.

50. Felder, C.C., R.Y. Kanterman, A.L. Ma, and J. Axelrod. 1989. A transfected $\mathrm{m} 1$ muscarinic acetylcholine receptor stimulates adenylate cyclase via phosphatidylinositol hydrolysis. J. Biol. Chem. 264:20356-20362.

51. Pan, G.-Z., M.J. Collen, and J.D. Gardner. 1982. Action of cholera toxin on dispersed acini from rat pancreas. Post-receptor modulation involving cyclic AMP and calcium. Biochim. Biophys. Acta. 720:338-345.

52. Baukal, A.J., L. Hunyady, K.J. Catt, and T. Balla. 1994. Evidence for participation of calcineurin in potentiation of agonist-stimulated cyclic AMP formation by the calcium-mobilizing hormone, Angiotensin II. J. Biol. Chem. 269:24546-24549.

53. Warhurst, G., K.E. Fogg, N.B. Higgs, A. Tonge, and J. Grundy. 1994. $\mathrm{Ca}^{2+}$-mobilizing agonists potentiate forskolin- and VIP-stimulated cAMP pro- duction in human colonic cell line, HT29-cl.19A: role of $\left[\mathrm{Ca}^{2+}\right]_{\mathrm{i}}$ and protein kinase C. Cell Calcium. 15:162-174.

54. Aminaroff, B.M., M.C. Laburthe, C.M. Rouyer-Fessard, J.G. Demaille, and G.E. Rossellin. 1983. Calmodulin stimulation of adenylate cyclase of intestinal epithelium. Eur. J. Biochem. 130:33-37.

55. Groblewski, G.E., C.C. Wagner, and J.A. Williams. 1994. Cyclosporin A inhibits $\mathrm{Ca}^{2+} /$ calmodulin-dependent protein phosphatase and secretion in pancreatic acinar cells. J. Biol. Chem. 269:15111-15117.

56. Raufman, J.P., J. Lin, and R.D. Raffaniello. 1996. Calcineurin mediates calcium-induced potentiation of adenylyl cyclase activity in dispersed chief cells from guinea pig stomach. J. Biol. Chem. 271:19877-19822.

57. Antoni, F.A., R.J.O. Barnard, M.J. Shipston, S.M. Smith, J. Simpson, and J.M. Paterson. 1995. Calcineurin feedback inhibition of agonist-evoked cAMP formation. J. Biol. Chem. 270:28055-28061.

58. Harrison, J.K., G.H.K. Hewlett, and M.E. Gnegy. 1989. Regulation of calmodulin-sensitive adenylate cyclase by the stimulatory G-protein, Gs. $J$. Biol. Chem. 264:15880-15885.

59. Cooperstein, S.J., and D.T. Watkins. 1995. $\mathrm{Ca}^{++}$)-calmodulin-dependent phosphorylation and dephosphorylation of rat parotid secretion granules. Biochem. Biophys. Res. Comm. 215:75-81.

60. Caldwell, K.K., C.L. Boyajian, and D.M.F. Cooper. 1992. The effects of $\mathrm{Ca}^{++}$and calmodulin on adenylyl cyclase activity in plasma membranes derived from neural and non-neural cells. Cell Calcium. 13:107-121.

61. Cooper, D.M.F., N. Mons, and J.W. Kerpen. 1995. Adenylyl cyclase and the interaction between calcium and cAMP signalling. Nature (Lond.). 374: 421-424.

62. Paterson, J.M., S.M. Smith, A.J. Harmar, and F.A. Antoni. 1995. Control of a novel adenylyl cyclase by calcineurin. Biochem. Biophys. Res. Comm. 214:1000-1008.

63. Tang, W.J., J. Krupinski, and A.G. Gilman. 1991. Expression and characterization of calmodulin-activated (type I) adenylyl cyclase. J. Biol. Chem. 266:8595-8603.

64. Choi, E.J., Z. Xia, and D.R. Storm. 1992. Stimulation of the type III olfactory adenylyl cyclase by calcium and calmodulin. Biochemistry. 31:64926498.

65. Cali, J.J., J.C. Zwaagstra, N. Mons, D.M.F. Cooper, and J. Krupinski. 1994. Type VIII adenylyl cyclase. A $\mathrm{Ca}^{2+} /$ calmodulin-stimulated enzyme expressed in discrete regions of rat brain. J. Biol. Chem. 269:12190-12195.

66. Salter, R.S., M.H. Krinks, C.B. Klee, and E.J. Neer. 1981. Calmodulin activates the isolated catalytic unit of brain adenylate cyclase. J. Biol. Chem. 256:9830-9833. 